\title{
Prdm13 Regulates Subtype Specification of Retinal Amacrine Interneurons and Modulates Visual Sensitivity
}

\author{
Satoshi Watanabe, ${ }^{1,2,3}$ Rikako Sanuki, ${ }^{1,2}$ Yuko Sugita, ${ }^{1,2}$ Wataru Imai, ${ }^{1}$ Ryoji Yamazaki, ${ }^{1,2}$ Takashi Kozuka, \\ Mizuki Ohsuga, ${ }^{1}$ and ${ }^{1}$ Takahisa Furukawa ${ }^{1,2}$ \\ ${ }^{1}$ Laboratory for Molecular and Developmental Biology, Institute for Protein Research, Osaka University, ${ }^{2}$ ST, Core Research for Evolutional Science and \\ Technology, 3-2 Yamadaoka, Suita, Osaka, 565-0871, Japan, and ${ }^{3}$ Kyoto University Graduate School of Medicine, Yoshida-konoe, Sakyo-ku, 606-8501, \\ Kyoto, Japan
}

\begin{abstract}
Amacrine interneurons, which are highly diversified in morphological, neurochemical, and physiological features, play crucial roles in visual information processing in the retina. However, the specification mechanisms and functions in vision for each amacrine subtype are not well understood. We found that the Prdm13 transcriptional regulator is specifically expressed in developing and mature amacrine cells in the mouse retina. Most Prdm13-positive amacrine cells are Calbindin- and Calretinin-positive GABAergic or glycinergic neurons. Absence of $\operatorname{Prdm} 13$ significantly reduces GABAergic and glycinergic amacrines, resulting in a specific defect of the S2/S3 border neurite bundle in the inner plexiform layer. Forced expression of Prdm13 distinctively induces GABAergic and glycinergic amacrine cells but not cholinergic amacrine cells, whereas Ptfla, an upstream transcriptional regulator of Prdm13, induces all of these subtypes. Moreover, Prdm13-deficient mice showed abnormally elevated spatial, temporal, and contrast sensitivities in vision. Together, these results show that Prdm13 regulates development of a subset of amacrine cells, which newly defines an amacrine subtype to negatively modulate visual sensitivities. Our current study provides new insights into mechanisms of the diversification of amacrine cells and their function in vision.
\end{abstract}

Key words: amacrine cell; interneuron; Prdm13; retina; subtype specification; visual function

\section{Introduction}

The vertebrate retina is a part of the CNS and responsible for the first step of vision. Amacrine cells are retinal interneurons that modulate visual information before transmission to ganglion cells enabling elaborate visual functions (Gollisch and Meister, 2010; Masland, 2012; Balasubramanian and Gan, 2014). Similarly to interneurons in other CNS regions such as the cortex, hippocampus, and spinal cord (Klausberger and Somogyi, 2008; Cossart, 2011), amacrine cells are classified into many different subtypes on the basis of morphological, neurochemical, and

Received Jan. 7, 2015; revised March 17, 2015; accepted April 20, 2015.

Author contributions: S.W. and T.F. designed research; S.W., Y.S., W.I., R.Y., T.K., M.O., and T.F. performed research; S.W., R.S., Y.S., and T.F. analyzed data; S.W., R.S., and T.F. wrote the paper.

This work was supported by Core Research for Evolutional Science and Technology from Japan Science and Technology Agency; Grants-in-Aid for Scientific Research on Innovative Areas; Grant-in-Aid for Scientific Research (B); Core Research for Evolutional Science and Technology Fellows (13J02346); Specially Designated Research Promotion and Scientific Research on Priority Areas from the Ministry of Education, Culture, Sports, Science and Technology of Japan; the Takeda Science Foundation; the Uehara Memorial Foundation; the Suzuken Memorial Foundation; and the Novartis Foundation (Japan) for the Promotion of Science. Mizuki Ohsuga is supported by the Osaka University Faculty of Medicine Medical Doctor Scientist Training Program. We thank Drs. Christopher V. Wright, Yoshiya Kawaguchi, and Yasuhiro Nakano for the Ptf1a-Cre mouse; Drs. Takahiko Matsuda and Constance L. Cepko for the pCIG plasmid; Dr. Francisco Zafra for the anti-Glyt1 antibody; and Akiko Tani, Mikiko Kadowaki, Aiko Ishimaru, Yoko Tojima, Katsura Hasegawa, Hiroko Abe, and Showna Kennedy for technical assistance.

The authors declare no competing financial interests.

Correspondence should be addressed to Dr. Takahisa Furukawa, Laboratory for Molecular and Developmental Biology, Institute for Protein Research, 0saka University, 3-2 Yamadaoka, Suita, 0saka, 565-0871, Japan. E-mail: takahisa.furukawa@protein.osaka-u.ac.jp.

DOI:10.1523/JNEUROSCI.0089-15.2015

Copyright $\odot 2015$ the authors $\quad 0270-6474 / 15 / 358004-17 \$ 15.00 / 0$ physiological profiles. Previous morphological analyses of amacrine cells revealed the existence of $\sim 30$ subtypes that are distinctive in arborization size and projection location for neurites (MacNeil and Masland, 1998; MacNeil et al., 1999). Whereas $\sim 85 \%$ of amacrine cells use GABA or glycine as a neurotransmitter (Grünert and Wässle, 1993; Menger et al., 1998; Kay et al., 2011), there are also amacrine cells releasing glutamate, acetylcholine, and dopamine, among others (Iuvone, 1986; Kolb, 1995; Haverkamp and Wässle, 2000). Moreover, some amacrine cells release neuromodulators, including neuropeptide Y (NPY), nitric oxide (NO), and substance P (Haverkamp and Wässle, 2000).

Transcription factors are known to play essential roles in amacrine cell development and diversification. In previous reports, Foxn 4 and Ror $\beta 1$, which are expressed in retinal progenitor cells, regulate amacrine and horizontal cell fate (Li et al., 2004; Liu et al., 2013). Ptfla, a common downstream factor of Foxn4 and Ror $\beta 1$, is also essential for amacrine and horizontal cell fate specification (Fujitani et al., 2006). Loss of the Barhl2 produces a reduction of GABAergic and glycinergic amacrine cells (Mo et al., 2004; Ding et al., 2009). Islet 1 homeoprotein deficiency results in a reduction of cholinergic amacrine cells (Elshatory et al., 2007b). Bhlhb5 deficiency leads to reduction of GABAergic amacrine cells (Feng et al., 2006), and Neurod6 overexpression induces the nGnG amacrine cells, which are neither GABAergic nor glycinergic (Kay et al., 2011). Nr4a2 (Nurr1) is known to specify a subset of GABAergic amacrine cells, including TH-positive amacrine cells (Jiang and Xiang, 2009). However, considering that there are 
$>30$ different subtypes of amacrine cells in the rodent retina, there still remains much to be clarified for our understanding of the specification mechanism of each amacrine cell subtype and its function in vision.

We previously reported that rod and cone cell fates were converted to those of amacrine-like cells in Otx2 conditional knockout (CKO) mouse retinas (Nishida et al., 2003; Sato et al., 2007). We hypothesized that transcripts from various genes important for amacrine cell development were relatively upregulated in the Otx2 CKO retina compared with those of the wild-type (WT) retina (Omori et al., 2011). We found that Prdm13 is a highly upregulated gene in Otx2 CKO retinas. In the current study, we identified Prdm13 (PR domain containing 13) as a regulator of amacrine subtype specification in the mouse retina. We found that the majority of Prdm13-positive amacrine cells express calcium-binding proteins, Calbindin and Calretinin (also known as CALB1 and CALB2 respectively, herein called CALBs) in the mouse retina. $\operatorname{Prdm13}$-null $\left(\operatorname{Prdm} 13^{-/-}\right)$retinas showed a specific reduction in the number of CALBs-positive GABAergic or glycinergic amacrine cells. Interestingly, $\operatorname{Prdm} 13^{-1-}$ retinas exhibited a specific defect of the S2/S3 border neurite bundle labeled by anti-CALBs antibodies in the inner plexiform layer (IPL). Finally, in optokinetic responses (OKRs), we observed elevated spatial, temporal, and contrast sensitivities in $\operatorname{Prdm} 13^{-1-}$ mice. Together, our current study reveals an essential role of $\operatorname{Prdm} 13$ in amacrine subtype specification in the retina and formation of proper visual acuity.

\section{Materials and Methods}

Animal care. All procedures conformed to the Association for Research in Vision and Ophthalmology statement for the Use of Animals in Ophthalmic and Vision Research, and these procedures were approved by the Institutional Safety Committee on Recombinant DNA Experiments (approval ID 3380-3) and Animal Experimental Committees of the Institute for Protein Research (approval ID 24-05-1), Osaka University, and were performed in compliance with the institutional guidelines. Mice were housed in a temperature-controlled room at $22^{\circ} \mathrm{C}$ with a $12 \mathrm{~h} \mathrm{light/dark}$ cycle. Fresh water and rodent diet were available at all times. All animal experiments were performed on mice of either sex.

In situ hybridization. In situ hybridization was performed as described previously (Sanuki et al., 2011). Mouse embryos and eye cups were fixed by $4 \%$ PFA in PBS overnight on ice. Digoxigenin-labeled riboprobes for mouse Prdm 13 and Nr4a2 were generated by in vitro transcription using 11-digoxigenin UTPs (Roche). Prdm 13 and Nr4a2 cDNA fragments were obtained by RT-PCR. Primer sequences used to synthesize radiolabeled probes are as follows: for the Prdm13 in situ hybridization probe, forward, 5' -GAATTCATGTACATCTGCTGGTACTGCTGGAGGA-3' and reverse, 5' -CTCGAGTTAGGAGTCGTGCTCGCCACGACC-3' and for the Nr4a2 cDNA fragment, forward, 5'-CTCGAGATGCCTTGTGTTCAGGCGCAGTAT-3' and reverse, 5'-GATATCTTAGAAA GGTAAGGTGTCCAGGAA-3'.

Northern blot analysis. Northern blot analysis was performed as described previously (Sanuki et al., 2011). Total RNAs were extracted from the mouse retina at $\mathrm{P} 0, \mathrm{P} 6, \mathrm{P} 9, \mathrm{P} 14$, and $\mathrm{P} 21$. A total of $10 \mu \mathrm{g}$ of total RNA was electrophoresed on a $1.0 \%$ agarose formaldehyde gel and transferred to a nylon membrane (Pall). The fragment (nucleotides 556-2265 in NM_001080771.1) of the Prdm13 cDNA obtained by PCR using the full-length $\operatorname{Prdm} 13$ cDNA was used to synthesize radiolabeled probes. The cDNA probe was labeled with ${ }^{32} \mathrm{P}$-dCTP using the Rediprime II random prime labeling system (GE Healthcare).

Immunohistochemistry. Immunohistochemistry was performed as described previously (Muranishi et al., 2011). Mouse embryos and eye cups were fixed by $4 \%$ PFA in PBS for 30 min at room temperature or on ice. The tissues were then rinsed in PBS, cryoprotected with 30\% sucrose in PBS, embedded in TissueTec OCT compound 4583 (Sakura), frozen, and sectioned. Frozen $16 \mu \mathrm{m}$ sections on slides were dried for $30 \mathrm{~min}$ at room temperature, rehydrated in PBS for $5 \mathrm{~min}$, incubated with blocking buffer (4\% normal donkey serum, and $0.1 \%$ Triton X-100 in PBS) for $1 \mathrm{~h}$, and then with primary antibodies overnight at $4^{\circ} \mathrm{C}$. Slides were washed with PBS three times for 10 min each time and incubated with secondary antibodies for $2 \mathrm{~h}$ at room temperature. For immunostaining of the whole retina, each retina was gently peeled off from the sclera, rinsed in PBS, and fixed with 4\% PFA (w/v) in PBS for $1.5 \mathrm{~h}$. The retinas were permeabilized by incubation in $0.1 \%$ Triton X-100 in PBS for $30 \mathrm{~min}$. The samples were blocked with $4 \%$ donkey serum in $0.1 \%$ Triton X-100 in PBS for $1 \mathrm{~h}$. The retinas were then incubated with primary antibodies at $4^{\circ} \mathrm{C}$ overnight. The samples were washed with PBS three times $10 \mathrm{~min}$ each time and incubated with a fluorescent dye-conjugated secondary antibody overnight at $4^{\circ} \mathrm{C}$. The specimens were observed under a laser confocal microscope (LSM700, Carl Zeiss). Primary antibodies used in this study are described as follows: anti-Rhodopsin (Sigma, O4886, mouse, 1:10,000), anti-S-opsin (Santa Cruz Biotechnology, sc14363, goat, 1:500), anti-Calbindin (Sigma, PC253L, rabbit, 1:1000), antiCalretinin (Millipore, AB5054, rabbit, 1:1000), anti-Chx10 (Koike et al., 2007, rabbit, 1:200), anti-Pax6 (DSHB, mouse, 1:100), anti-Brn3a (Millipore, MAB1585, mouse, 1:100), anti-Brn3b (Santa Cruz Biotechnology, sc-6026, goat, 1:100), anti-S100 $\beta$ (Sigma, S-2532, mouse, 1:100), antiGad65/67 (Millipore, AB1511, rabbit, 1:1000), anti-Gad65 (Sigma, G-4913, rabbit, 1:1000), anti-Glyt1 (Millipore, AB1770, goat, 1:1000 or Zafra et al., 1995, rabbit, 1:500), anti-TH (Millipore, MAB5280, mouse, 1:1000), anti-AP- $2 \alpha$ (Novus Biological, NBP1-95386, rabbit, 1:1000), antiAP-2 $\gamma$ (Sigma, A3108, mouse, 1:1000), anti-Islet1 (DSHB, 39.4D5, mouse, $1: 1000$ ), anti-BrdU (Becton Dickinson, 347580, mouse, 1:100), anti-GFP (Nacalai, 04404-26, rat, 1:1000), anti-GFP (Clontech, 632460, rabbit, 1:1000), anti-Syntaxin (Sigma, S-0664, mouse, 1:1000), anti-Vglut3 (Millipore, AB5421, guinea pig, 1:1000), anti-Calsenilin (Millipore, 05756, mouse, 1:100), anti-active Caspase-3 (Promega, G748A, rabbit, 1:500), anti-phospho-Histone H3 (Millipore, 06-570, rabbit, 1:100), antiKi67 (BD Pharmingen, 556003, mouse, 1:500), anti-Lhx2 (Santa Cruz Biotechnology, sc-19342, goat, 1:200), and anti-Prdm13 (current study, guinea pig, 1:1000).

S-phase labeling. The S-phase labeling experiment was performed as described previously (Muranishi et al., 2011). Timed pregnant mice (ICR, E15.5) were injected intraperitoneally with BrdU (50 $\mu \mathrm{g} / \mathrm{g}$ body weight). Embryos were harvested $1 \mathrm{~h}$ after BrdU injection and fixed with $4 \%$ PFA for $30 \mathrm{~min}$ on ice. For BrdU immunostaining, sections were pretreated with $2 \mathrm{~N} \mathrm{HCl}$ for $15 \mathrm{~min}$ at $37^{\circ} \mathrm{C}$ before blocking.

Generation of Prdm13 flox mouse. We subcloned an $\sim 10 \mathrm{~kb}$ Prdm13 genomic fragment, inserted one loxP site into intron 1 and another loxP site into intron 3, cloned it into a modified pPNT vector to make a targeting construct, and transfected the linearized targeting construct into the JM8A3 ES cells (Pettitt et al., 2009). The culture, electroporation, and selection of ES cells were performed as described previously (Muranishi et al., 2011). ES cells that were heterozygous for the targeted gene disruption were microinjected into ICR (Charles River) blastocysts to obtain chimeric mice. We obtained $\operatorname{Prdm} 13$ conventional knock-out (KO) mice by crossing a Prdm13 flox mouse line with the CAG-Cre transgenic mouse line, which expresses Cre recombinase driven under the CAG promoter (Sakai and Miyazaki, 1997). We also obtained retinal progenitor CKO mice of $\operatorname{Prdm} 13$ by crossing the Prdm13 flox mouse line with the Dkk3-Cre transgenic mouse line expressing Cre in retinal progenitors (Sato et al., 2007). The $r d 8$ mutation carried in the C57BL/6N strain (Mattapallil et al., 2012) was removed by outcrossing the mice with the C57BL/6J strain before the mice were used for experiments. Primer sequences for genotyping are as follows: for genotyping of $\operatorname{Prdm} 13$ flox mouse, forward, 5'-AGCCTAGAGCTCATAAGCGAATGG-3' and reverse, 5'-ATAGGACAGGAAGGACCCATGAAG-3'; genotyping of Prdm13-null mouse, forward, 5' -CACCTCAGTCTTTGCCTTCCTTGCAA- $3^{\prime}$, reverse $1,5^{\prime}$-CTACAACTGCGACTCCAACGCATGAT-3' and reverse 2, 5' -CAGAGAAAGAGTACCCTTGTGCCT-3'

Western blot analysis. P14 mouse retinas were lysed in a SDS-sample buffer. Samples were resolved by SDS-PAGE and transferred to a PVDF membrane. The membrane was blocked with blocking buffer (5\% skim milk (w/v), and $0.1 \%$ Tween 20 in TBS) and was incubated with an 
anti-Prdm13 antibody that we raised. The membrane was washed with $0.1 \%$ Tween 20 in TBS and incubated with an HRP-conjugated goat antibody against guinea pig IgG (1:10,000, 706-035-148, Jackson ImmunoResearch Laboratories). For the secondary immunoreaction, the PVDF membrane was incubated with WB Stripping Solution (Nacalai) to remove antibodies for the first reaction, and blocked again with $5 \%$ skim milk (w/v) in TBS. Further immunoblots were performed using a mouse antibody against $\beta$-actin (1:500, A5316, Sigma). After washing, the membrane was incubated with an HRP-conjugated goat antibody against mouse antibody IgG (1:10,000, 81-6520, Zymed). $\beta$-actin was used as a loading control.

Toluidine blue staining. Retinal sections were rinsed with PBS then stained with $0.1 \%$ toluidine blue in PBS for $1 \mathrm{~min}$. After washing with PBS three times for 1 min each time, slides were coverslipped and immediately observed under the microscope.

Plasmid constructs. Full-length cDNA fragments of mouse Prdm13 (GenBank accession no. NM_001080771.1) and Ptf1a (NM_018809.2) were amplified by PCR using retinal cDNAs from E17 mouse embryos and cloned into the pCRII-TOPO vector (pCRII-TOPO-mPrdm13, Invitrogen). Full-length Prdm13 and Ptf1a were digested with EcoRI and XhoI and subcloned into the pCIG vector (Matsuda and Cepko, 2004). The pCIG vector contains an IRES-EGFP sequence to express EGFP in a bicistronic manner. Prdm13 mutants, named PR domain, zinc finger, and zinc finger mutant, were amplified by PCR using pCRII-TOPO$\mathrm{mPrdm} 13$ as a template, cloned into pCRII-TOPO (Invitrogen), and ligated into the pCIG vector digested with EcoRI and XhoI. All cDNA clones obtained by PCR in the current study were validated by sequencing. Primer sequences are as follows: for a full-length $\operatorname{Prdm} 13$, forward, 5'-GAATTCATGCCCGCCCACGTCACTCCGCGGA-3' and reverse, 5' -CTCGAGTTAGGAGTCGTGCTCGCCACGACC-3'; Prdm13 PRdomain, forward, 5'-GAATTCATGCCCGCCCACGTCACTCCG CGGA-3' and reverse, 5'-CTCGAGTCAGTAGCGCTCCTCCCC TTTCTCATCA-3' ${ }^{\prime}$ Prdm 13 zinc finger domain, forward, $5^{\prime}$-GA ATTCATGTACATCTGCTGGTACTGCTGGAGGA- ${ }^{\prime}$ and reverse, $5^{\prime}$ CTCGAGTTAGGAGTCGTGCTCGCCACGACC-3'; Prdm13 zinc finger mutant, forward 1, 5' ${ }^{\prime}$-TAACAGCCTCAAGGCACACCTGCGGTTCGCCTGCGTCCTC-3' and reverse 1, 5'-GGGTAGCGAAAG GTCCTCCAGCAGTACCAGGCGATGTAGC-3', forward 2, 5' CGCGCAAGTACGGGCTCAAGATCGCCATGCGGACGCACAC-3' and reverse 2, 5' -AGTACAGCTTGCCACAGTAGAGGGCCAAGTGGCCTGTCTT-3', forward 3, 5'-GCGACCCCAGCAATCTCAACAAGGCCATCCGACTCCACGC-3' and reverse 3, 5' -CGAAGGGCC GCAGGCACACACTTTGGCCTTGAGCGGCTTGTA-3', forward 4, 5' -CCAGCCACCTTGCCGGCGAACTCGCAGCGGTAGGGCGTATT-3' and reverse $4,5^{\prime}$-TGCGCCGCCGAGACCTGGAGCGTGCCGTCAAGTCCCGCCA-3'; a full-length Ptfla, forward, 5'-GAATTCATGGACGCC GTACTCCTGGAGCACTT- ${ }^{\prime}$ and reverse, 5' -CTCGAGTCAGGAACA CAAACTCAAAGGGTGG-3'.

In vivo electroporation. In vivo electroporation was performed on the P0 mouse retina as described previously (Matsuda and Cepko, 2004). Plasmids in $0.4 \mu \mathrm{l}$ of PBS at a concentration of $5 \mu \mathrm{g} / \mu \mathrm{l}$ were injected into P0 mouse retinas followed by in vivo electroporation. The electroporated retinas were harvested at $\mathrm{P} 6$ and were immunostained using antibodies against GFP, Rhodopsin, Chx10, and Pax6.

$E R G$ recording. ERGs were recorded with a white LED luminescent electrode placed on the cornea (PuREC). One-month-old mice were dark adapted overnight and anesthetized with an intraperitoneal injection of $100 \mathrm{mg} / \mathrm{kg}$ ketamine and $10 \mathrm{mg} / \mathrm{kg}$ xylazine, and then the mice were placed on a heating pad. The mice were stimulated with an LED flash. Four levels of stimulus intensities ranging from -4.0 to $1.0 \mathrm{log}$ $\mathrm{cd}-\mathrm{s} / \mathrm{m}^{2}$ were used for the scotopic ERG recordings, and four levels of stimuli ranging from -0.5 to $1.0 \mathrm{log} \mathrm{cd}-\mathrm{s} / \mathrm{m}^{2}$ were used for the photopic ERG recordings. After mice were light adapted for $10 \mathrm{~min}$, the photopic ERGs were recorded on a rod-suppressing white background of $1.3 \mathrm{log}$ $\mathrm{cd}-\mathrm{s} / \mathrm{m}^{2}$. Eight responses were averaged for scotopic recordings $(-4.0$ and $\left.-3.0 \log \mathrm{cd}-\mathrm{s} / \mathrm{m}^{2}\right)$. Sixteen responses were averaged for photopic recordings. Oscillatory potentials were extracted from the brightest flash scotopic and photopic ERGs by bandpass filtering between 50 and $170 \mathrm{~Hz}$ (Heynen et al., 1985; Wachtmeister, 1998).
OKR recording. OKR recording was performed as previously described in detail (Sugita et al., 2013). Data were collected from WT mice and Prdm $13^{-1-}$ mice weighing $17-26$ g. Each mouse was previously implanted with a head holder, which allowed the head to be fixed in the stereotaxic position during the experiments. Eye movement of the right eye of each mouse was measured using a video-based eye tracker system (Geteye, Matsuura-Denko-sha). The visual stimuli were moving sinusoidal gratings with one of five spatial frequencies selected randomly from a lookup table: $0.0313,0.0625,0.125,0.25$, and $0.5 \mathrm{cycle} / \mathrm{deg}$ in a given trial. The temporal frequency was selected from $0.1875,0.375,0.75,1.5,3,6$, 12 , or $24 \mathrm{~Hz}$. To compare the contrast sensitivity, we used contrast of $1 \%$, $2 \%, 4 \%, 8 \%, 16 \%, 32 \%, 64 \%$, and $96 \%$ (sinusoidal grating; mean luminance, $100 \mathrm{~cd} / \mathrm{m}^{2}$ ). We set the spatial frequency and temporal frequency to $0.125 \mathrm{cycle} / \mathrm{deg}$ and $1.5 \mathrm{~Hz}$, respectively. We calculated the mean eye velocity for initial phase.

Antibody production. A cDNA encoding a C-terminal portion of mouse Prdm13 (685-754 amino acids) was amplified by PCR and subcloned into pGEX4T-1 (GE Healthcare). The fusion protein was expressed in Escherichia coli strain BL21 and purified with glutathione Sepharose 4B (GE Healthcare) according to the manufacturer's instructions. An antiserum against Prdm13 was obtained by immunizing guinea pigs with the purified GST-Prdm13. Antibodies against GST in the antiserum were removed by incubation with the GST-coupled CNBractivated Sepharose4B (GE Healthcare). Then, antibodies against C-terminal Prdm13 were affinity purified with GST-Prdm13-coupled CNBr-activated Sepharose4B column.

Statistical analysis. Data are presented as mean \pm SEM in ERG analysis and $\pm \mathrm{SD}$ in the other analyses. Statistical significance was calculated with Student's $t$ test, and $p<0.05$ was taken to be statistically significant.

\section{Results}

Prdm13 is expressed specifically in a subset of amacrine cells

To examine the expression pattern of $\operatorname{Prdm} 13$ in the developing mouse retina, we performed in situ hybridization using retinas at different developmental stages from embryonic day 11.5 (E11.5) to postnatal day 21 (P21). Prdm13 expression began at E12.5 in the mouse retina and was observed in the neuroblastic layer (NBL) through the embryonic stages (Fig. 1A). Prdm13-positive cells were gradually stacked in the inner nuclear layer (INL) from P6 to P21 and were confined to the innermost INL where amacrine cells are localized. This result suggests that $\operatorname{Prdm} 13$ is predominantly expressed in amacrine cells. Northern blot analysis using retinal RNAs showed that $\operatorname{Prdm} 13$ expression is gradually reduced from P9 but is maintained into adulthood (Fig. 1B). To further investigate which retinal cell types express Prdm13, we raised an antibody against mouse Prdm13 and performed coimmunostaining with an anti-Pax6 antibody (a pan-amacrine cell marker in the INL) or an anti-Brn3a/b antibody (a ganglion cell marker) on the mouse retina at P14 when all the retinal cell types have completed differentiation (Cepko et al., 1996). Consistent with the observation in in situ hybridization (Fig. 1A), Prdm13 signals were detected predominantly in the INL and all of the Prdm $13^{+}$cells were Pax6-positive (Fig. 1C). Prdm $13^{+}$cells accounted for $32.0 \pm 2.5 \%$ of the Pax $6^{+}$cell population in the INL at P14 (Fig. 1C), and this ratio was similar with that at P9 when the Prdm13 expression level was much higher $(31.7 \pm 1.0 \%$; Fig. $1 D)$. We also observed that Prdm13 is expressed in a small population of cells in the ganglion cell layer (GCL) where ganglion cells and displaced amacrine cells are localized (Fig. 1C,E, arrowheads). Because Prdm $13^{+}$cells in the GCL did not express Brn3a/b (Fig. $1 E$ ), these cells are very likely to be displaced amacrine cells. These results showed that Prdm13 is expressed specifically in a subset of amacrine cells. To further characterize Prdm $13^{+}$cells, we immunostained P14 mouse retinas with antibodies against Gad65, Glyt1, AP- $2 \alpha$, AP-2 $\gamma$ (also known as 

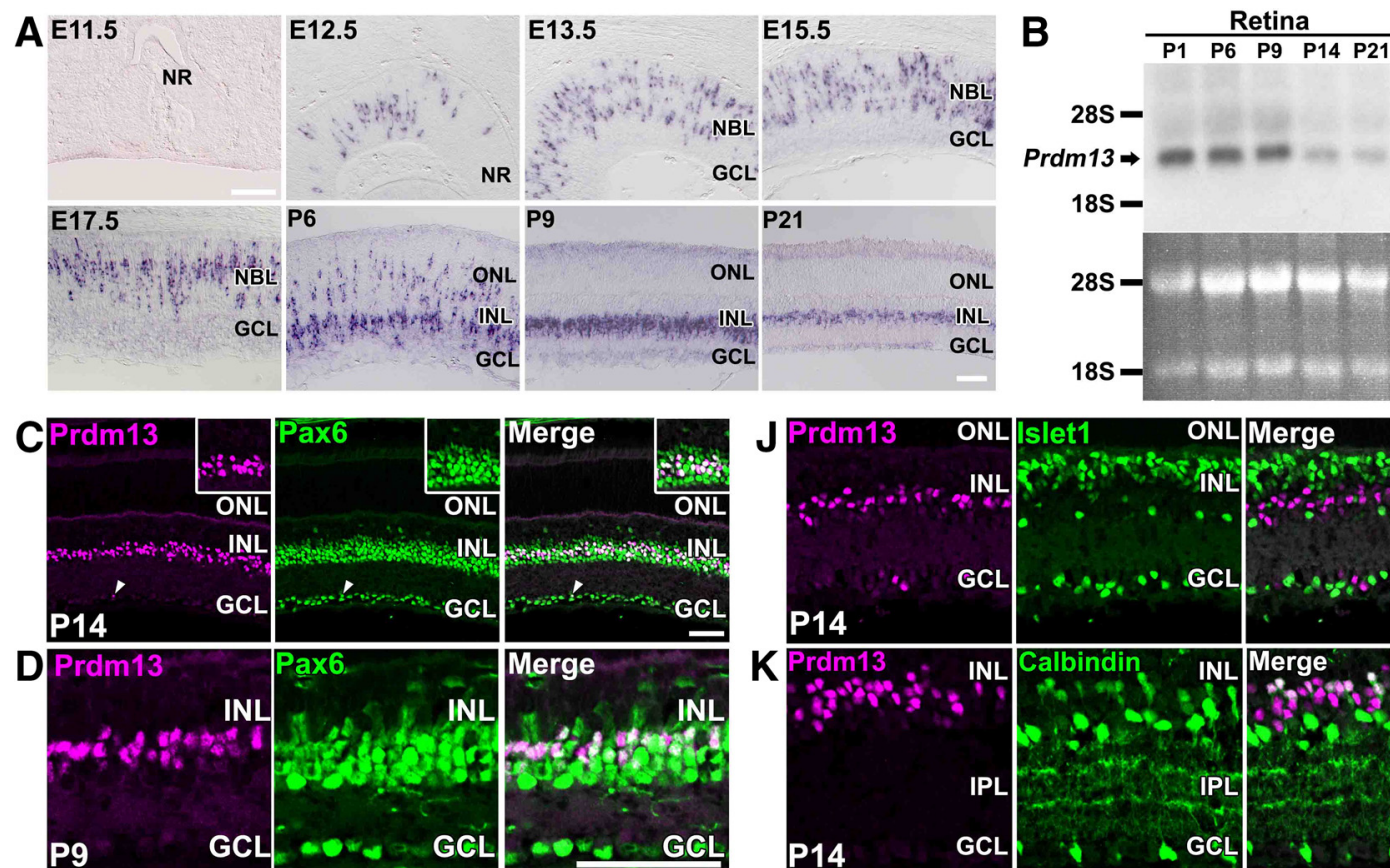

$28 \mathrm{~S}=$

Prdm13 $\Rightarrow$

$185-$
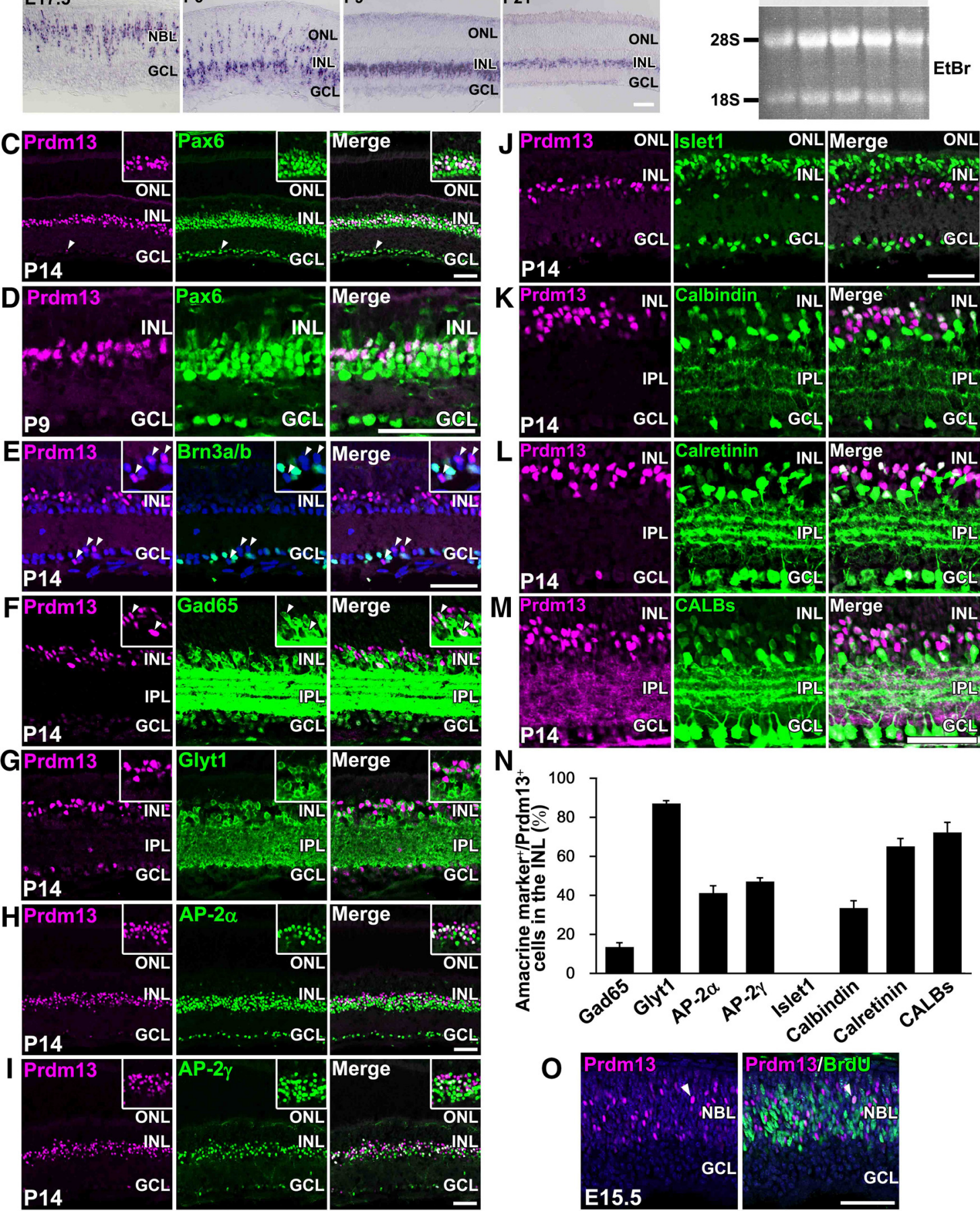

$\mathbf{L}$

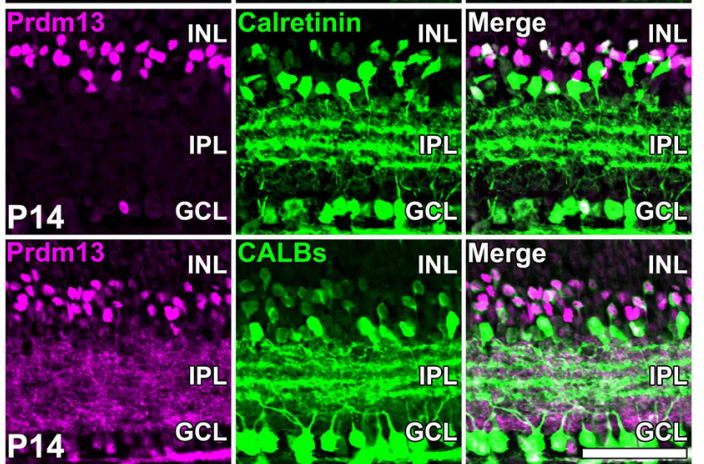

N
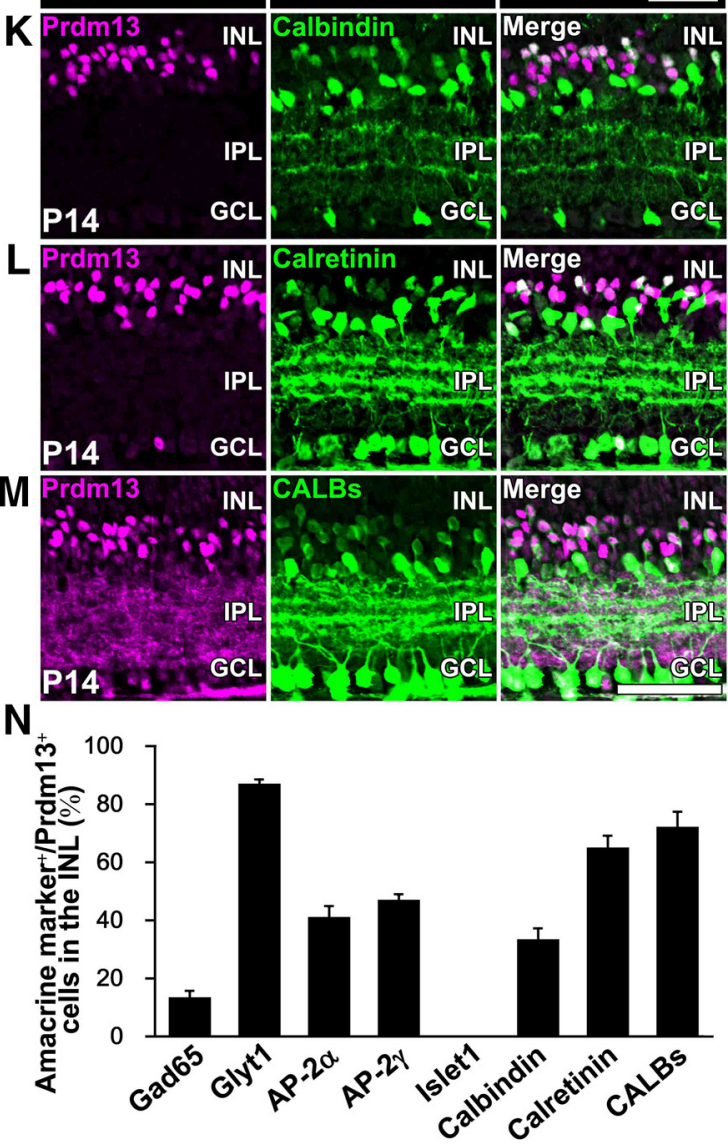

0

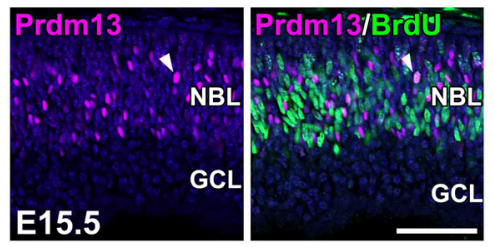

Figure 1. Prdm13 is specifically expressed in a subset of amacrine cells in the mouse retina. $A$, In situ hybridization of Prdm13 using mouse retinas at developing (E11.5-P9) and mature (P21) stages. B, Northern blots of Prdm13 transcripts using developing (P1-P14) and mature (P21) mouse retinal total RNAs. The arrow indicates an $\sim 3.2 \mathrm{~kb}$ Prdm13 full-length mRNA. Bottom, Ethidium bromide (EtBr) staining of the RNAs. $18 \mathrm{~S}$ and 28S rRNAs are indicated. $C-M$, Prdm 13 localization in the mouse retina. Mouse retinas at P14 and P9 were immunostained with antibodies against Prdm13 (magenta) and pan-amacrine, ganglion cell, or amacrine subtype markers (green): Pax6 (a pan-amacrine cell marker, $\boldsymbol{C}, \boldsymbol{D})$, Brn3a/b (ganglion cell markers, $\boldsymbol{E}), \mathrm{Gad} 65$ (F), Glyt1 (G), AP-2 $\alpha$ $(\boldsymbol{H})$, AP-2 $\gamma(\boldsymbol{I})$, Islet1 $(\boldsymbol{J})$, Calbindin $(\boldsymbol{K})$, Calretinin $(\boldsymbol{L})$, and Calbindin plus Calretinin (CALBs, M). Arrowheads indicate Prdm $13^{+}$displaced amacrine cells and Prdm13 ${ }^{+} / \mathrm{Gad} 65^{+}$amacrine cells $\left(\boldsymbol{C}, \boldsymbol{E}, \boldsymbol{F}\right.$, respectively). Insets, INL and $G C L$ areas with high magnification $\left(\boldsymbol{C}, \boldsymbol{F}, \boldsymbol{G}, \boldsymbol{H}, \boldsymbol{I}\right.$, and $\boldsymbol{E}$, respectively). $\boldsymbol{N}$, The percentages of each amacrine subtype marker ${ }^{+}$cells of Prdm $13^{+}$cells in the INL. Error bars indicate SD from the means of 3 or 4 different mice. O, Labeling of S-phase proliferating cells with an anti-BrdU antibody (green) in mouse retinas at E15.5. Prdm13 and BrdU double-positive cells were rarely observed (arrowhead). Nuclei were stained by Hoechst (blue signals). Scale bars, $50 \mu \mathrm{m}$. 
Tcfap $2 \mathrm{a}$ and 2c, respectively), Islet1, Calbindin, and Calretinin (Fig. $1 F-M$ ). Gad65 and Glyt1 are markers for GABAergic and glycinergic amacrine cells, respectively. We observed coexpression of Prdm13 with Gad65 or Glyt1 (13.5 $\pm 2.0 \%$ and $87.1 \pm 1.4 \%$, respectively; Fig. $1 F, G, N)$. AP- $2 \alpha$ and AP- $2 \gamma$ are transcription factors expressed in GABAergic and glycinergic amacrine cells and associated with amacrine cell development (Bassett et al., 2012). We found that subsets of Prdm $13^{+}$amacrine cells were AP $-2 \alpha^{+}$or AP- $2 \gamma^{+}$ cells $(41.2 \pm 3.7 \%$ and $47.1 \pm 1.7 \%$, respectively; Fig. $1 H, I, N)$. Islet1 is a marker for cholinergic amacrine cells, called starburst amacrine cells, and involved in direction selectivity (Elshatory et al., 2007a). We observed that none of the Prdm $13^{+}$amacrine cell signals was colocalized with Islet 1 signals (Fig. $1 J$ ), indicating that Prdm13 is not expressed in starburst amacrine cells. CALBs label horizontal cells, a type of ganglion cell and a subset of amacrine cells, including starburst amacrine cells and other amacrine subtypes containing GABA, NO, and/or substance $\mathrm{P}$ in the mouse retina (Haverkamp and Wässle, 2000; Mojumder et al., 2008). In rabbits and primates, AII amacrine cells, which transmit inputs from rod photoreceptor cells to cone bipolar cells, express CALBs, but in rodents AII amacrine cells do not express CALBs (Wässle et al., 1995; Volgyi et al., 1997; Gábriel and Witkovsky, 1998).

Calbindin $^{+}$or Calretinin ${ }^{+}$amacrine cells made up $33.5 \pm$ $3.7 \%$ and $65.1 \pm 3.9 \%$ of $\operatorname{Prdm} 13^{+}$amacrine cells, respectively (Fig. $1 K, L, N)$. Total CALBs ${ }^{+}$amacrine cells were $72.2 \pm 5.0 \%$ of $\operatorname{Prdm} 13^{+}$amacrine cells (Fig. $1 M, N$ ). We therefore found that the major population of Prdm $13^{+}$amacrine cells expresses CALBs. Finally, we examined Prdm13 expression in S-phase proliferating cells in the E15.5 retina. Almost none of the Prdm $13^{+}$ cells colocalized with $\mathrm{BrdU}^{+}$cells (S-phase proliferating cells in this experiment) (Fig. 1O), suggesting that Prdm13 is expressed specifically in postmitotic cells. Together, these results showed that almost all of the Prdm $13^{+}$amacrine cells are GABAergic or glycinergic, and that the majority of Prdm $13^{+}$amacrine cells are $\mathrm{CALBs}^{+}$, except for starburst amacrine cells.

\section{Targeted deletion of Prdm13 leads to a specific reduction of amacrine cells}

To investigate the in vivo functions of $\operatorname{Prdm} 13$ in the retina, we generated $\mathrm{Prdm} 13$-null mutant mice by targeted gene disruption (Fig. 2A-C). We confirmed the loss of Prdm13 expression in the Prdm $13^{-1-}$ retinas by immunostaining and Western blot analysis with an anti-Prdm13 antibody using retinas from WT and $\operatorname{Prdm} 13^{-/-}$mice at P14 (Fig. 2D,E). The Prdm13 $3^{-/-}$mice were viable and fertile, and did not show any prominent appearance abnormalities. We first examined WT and $\operatorname{Prdm} 13^{-1-}$ retinas at P14 by immunohistochemistry using an anti-Syntaxin antibody, a pan-amacrine marker. We found that amacrine cell numbers in the INL notably decreased in the $\operatorname{Prdm} 13^{-1-}$ retina (Fig. $2 F$ ). We next examined overall retinal morphology and layer thickness by toluidine blue staining in WT and $\operatorname{Prdm} 13^{-1-}$ retinas at P14. $\operatorname{Prdm} 13^{-1-}$ retinas exhibited normal layer thickness of the outer nuclear layer (ONL) and GCL, but a thinner INL compared with that in the WT retina (Fig. $2 G$ ). We measured layer thickness of WT and $\operatorname{Prdm} 13^{-1-}$ retinas (Fig. $2 H$ ). Whereas the ONL thickness was unchanged, the INL+IPL and INL thicknesses were significantly thinner in the $\operatorname{Prdm} 13^{-1-}$ retina (Fig. $2 H$ ). We then immunostained major cell types in WT and $\operatorname{Prdm} 13^{-1-}$ retinas at P14 (Fig. 2I-O). In Prdm 13 ${ }^{-1-}$ retinas, the amacrine cell number decreased to approximately half of that in WT retinas (Fig. 2O).

We further examined the retinal architecture of WT and $\operatorname{Prdm} 13^{-/-}$retinas at 5 months of age by toluidine blue staining
(Fig. $3 A, B$ ). We observed that the thicknesses of the INL+IPL, INL, and IPL were significantly less than those in $\operatorname{Prdm} 13^{-1-}$ mice at 5 months on a similar level with those of in $\operatorname{Prdm}_{13}^{-1-}$ retinas at P14, except for the IPL. The ONL thickness was unaltered between WT and $P r d m 13^{-1-}$ retinas. We examined whether apoptosis increases in the developing $\operatorname{Prdm} 13^{-1-}$ retinas compared with WT retinas at $\mathrm{P} 3$ and $\mathrm{P} 14$ by active Caspase- 3 immunostaining (Fig. 3C,D). We detected no significant increase of active Caspase- 3 signals in the $\operatorname{Prdm13^{-/-}}$ retina. These results suggest that amacrine cell reduction did not significantly affect the maintenance of other cell types.

\section{GABAergic and glycinergic amacrine cells are reduced in $\operatorname{Prdm} 13^{-1-}$ retinas}

To investigate what subtypes of amacrine cells decreased in the $\operatorname{Prdm} 13^{-1-}$ retina, we analyzed cell numbers of eight subtypes of amacrine cells in WT and Prdm13 ${ }^{-1-}$ retinas at P14 by immunostaining. We immunolabeled GABAergic and glycinergic amacrine cells using anti-Gad65/67 and anti-Glyt1 antibodies, respectively. We found that cell numbers of both GABAergic and glycinergic amacrine cells decreased in the $\operatorname{Prdm} 13^{-/-}$retina (Fig. $4 A, B, K)$. Consistent with a reduction of GABAergic and glycinergic amacrine cells in the $\operatorname{Prdm} 13^{-1-}$ retina, both AP- $2 \alpha^{+}$ and $\mathrm{AP}-2 \gamma^{+}$amacrine cells significantly decreased in the $\operatorname{Prdm} 13^{-1-}$ retina (Fig. $4 C, D, K$ ). Islet1- and Calbindin-double positive amacrine cell populations represent cholinergic amacrine cells, including starburst amacrine cells. We did not observe any changes in cell number of cholinergic amacrine cells by counting Islet ${ }^{+}{ }^{+}$and Calbindin ${ }^{+}$amacrine cells (Fig. $4 E, K$ ). We immunostained dopaminergic and glutamatergic amacrine cells using anti-TH and anti-Vglut3 antibodies, respectively. We observed that cell numbers of dopaminergic and glutamatergic amacrine cells were unaltered in the $\operatorname{Prdm} 13^{-1-}$ retina compared with those in the WT retina (Fig. $4 F-I, L$ ). Furthermore, we performed in situ hybridization on WT and $\operatorname{Prdm} 13^{-1-}$ retinas at P9 using the Nr4a2 probes. Whereas the numbers of $\mathrm{Nr}_{4} \mathrm{a}^{+}$amacrine cells in the INL were unchanged, the numbers of $\mathrm{Nr}_{\mathrm{aa}}{ }^{+}$ displaced amacrine cells in the GCL significantly decreased (Fig. $4 J, M) . N r 4 a 2^{+}$displaced amacrine cells are GABAergic, not THpositive, amacrine cells (Jiang and Xiang, 2009). In summary, the $\operatorname{Prdm} 13^{-/-}$retina displayed a significant reduction in cell numbers of GABAergic and glycinergic amacrine cells of the eight subtypes we examined.

\section{Prdm13 potently induces amacrine cell differentiation}

To test whether Prdm13 can induce amacrine cell differentiation, we overexpressed Prdm13 in the developing mouse retina by in vivo electroporation. We generated a $\mathrm{pCIG}-\operatorname{Prdm} 13$ plasmid that simultaneously expresses full-length $\operatorname{Prdm} 13$, driven by the $C A G$ promoter, and EGFP in a bicistronic manner mediated by the IRES sequence (Matsuda and Cepko, 2004). The pCIG plasmid without the cDNA insert was used as a control. These plasmids were in vivo electroporated into mouse retinas at $\mathrm{P} 0$ when rods, bipolar cells, and amacrine cells are the neurons being generated in addition to Müller glial cells. At this stage, the proliferating retinal progenitors basically express electroporated genes. We harvested the retinas at P6 and analyzed by immunostaining using an anti-GFP antibody together with retinal neuronal type marker antibodies (an anti-Rhodopsin antibody for rods, an anti-Chx10 antibody for bipolar cells, and an anti-Pax6 antibody for pan-amacrine cells; Fig. 5A). We quantified percentages of retinal cell marker-positive cells in the EGFP-positive cells (Fig. $5 B)$. In pCIG-transfected retinas, $\mathrm{EGFP}^{+}$cells differentiated into 

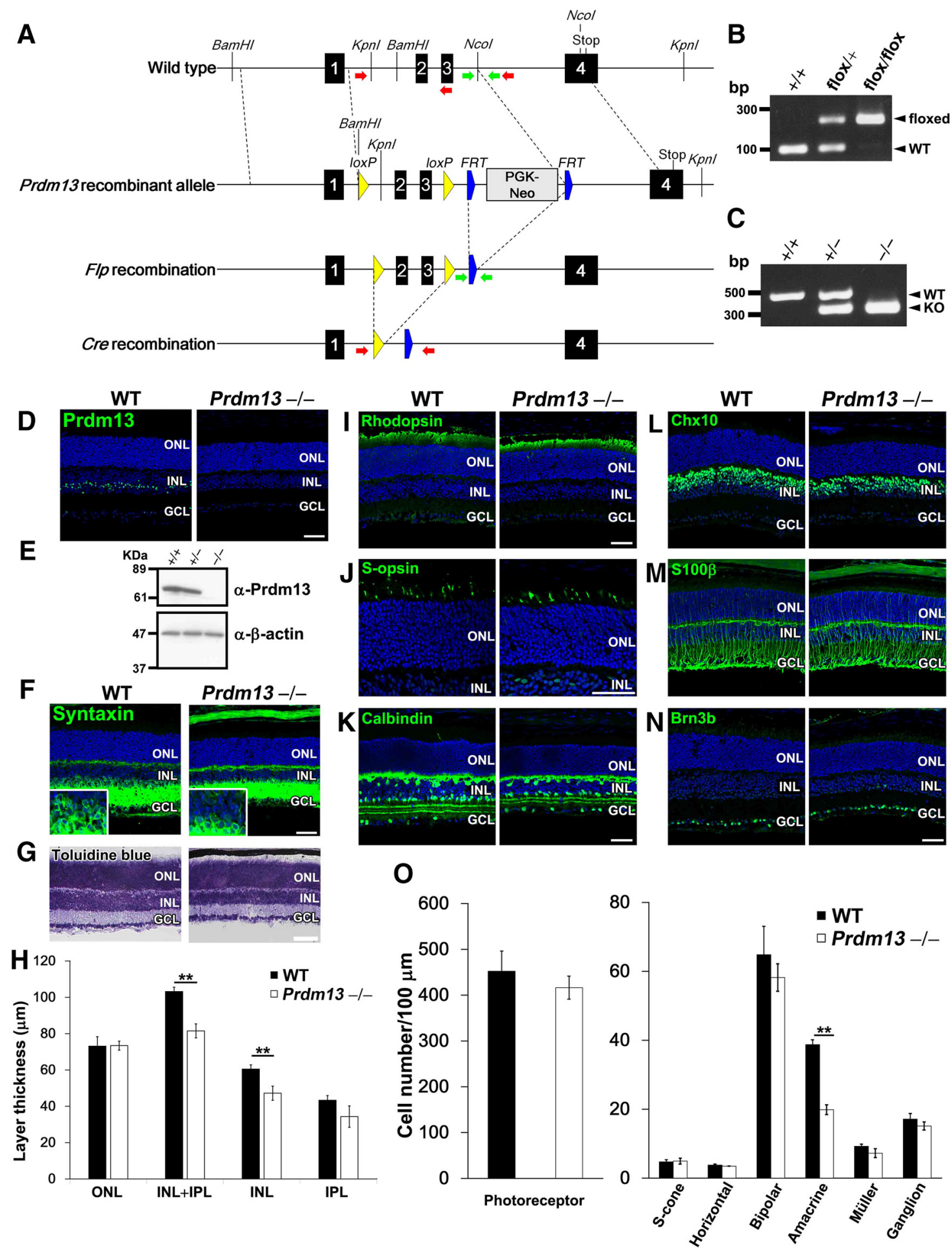

Figure 2. Loss of Prdm13 leads to a specific reduction of amacrine cells. A, Schematic representation of the Prdm13 wild-type allele, Prdm 13 recombinant allele, Flp recombinant allele, and Cre recombinant allele. Black boxes represent exons. Yellow arrowheads represent /oxP sites. Blue pentagons represent $F R T$ sites. Green and red arrows indicate primer sets to detect the FIp recombinant allele and Cre recombinant allele, respectively. Removal of the floxed region by Cre-mediated recombination is predicted to result in a translational frame shift and complete loss of Prdm 13 function. $\boldsymbol{B}$, PCR products of 98 and $200 \mathrm{bp}$ were amplified from the WT and flox allele, respectively. C, PCR products of 463 and 262 bp were amplified from the WT and K0 allele, respectively. D, E, Expression of the Prdm 13 protein in WT and Prdm 13 ${ }^{-1-}$ mouse retinas at P14. WT and Prdm $13^{-1-}$ retinas at P14 were immunostained with an anti-Prdm13 antibody (green) (D). The Prdm13 signals in the INL disappeared in the Prdm13 ${ }^{-/-}$retina. Western blots of Prdm13 protein in WT, Prdm $13^{+/-}$, and Prdm $13^{-/-}$mouse retinas at P14 (E). $\beta$-actin was used as a loading control. $\boldsymbol{F}$, WT and Prdm $13^{-1-}$ retinas at P14 were immunostained with an antibody against Syntaxin (green), a pan-amacrine cell marker. Insets, INL area with high magnification $(\boldsymbol{F}) . \mathbf{G}, \boldsymbol{H}$, Toluidine blue staining of WT and Prdm $13^{-/-}$retinas at P14. Thicknesses of ONL, INL, INL +IPL, and IPL were measured $(\boldsymbol{H}) . \mathbf{I - O}$, Immunostaining of WT and Prdm $13^{-/-}$retinas at P14 with antibodies against major cell type-specific markers (green): Rhodopsin (a rod photoreceptor marker, $\boldsymbol{I}$ ), S-opsin (an S-cone photoreceptor marker, $\boldsymbol{J}$ ), Calbindin (a horizontal cell marker, $\boldsymbol{K}$ ), Chx10 (a pan-bipolar cell marker, L), S100 $\beta$ (Müller glia cell marker, $\boldsymbol{M}$ ), and Brn3b (a ganglion cell marker, $\boldsymbol{N}$ ). Nuclei were stained by Hoechst (blue signals). The numbers of major cell types were counted in P14 WT and Prdm $13^{-I-}$ retinas (0). Error bars indicate SD from the means of 3 or 4 different mice. ${ }^{* *} p<0.01$. Scale bars, $50 \mu \mathrm{m}$. 
A

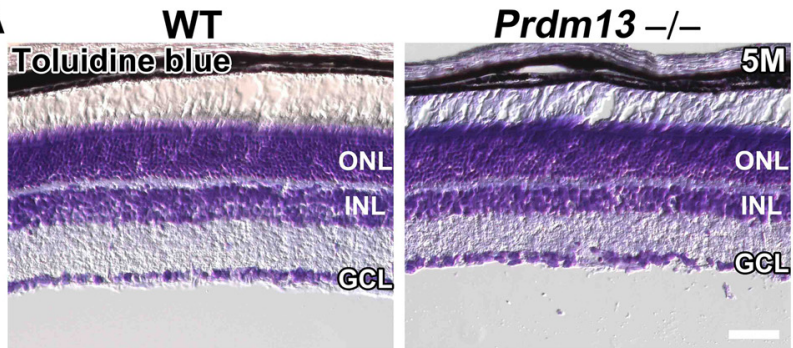

B
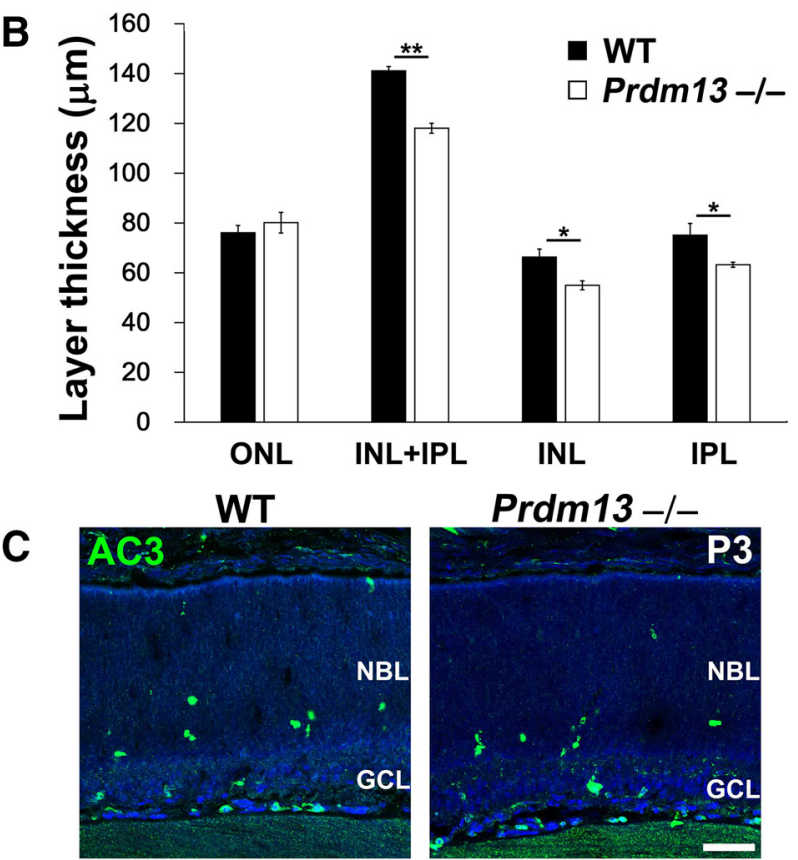

D
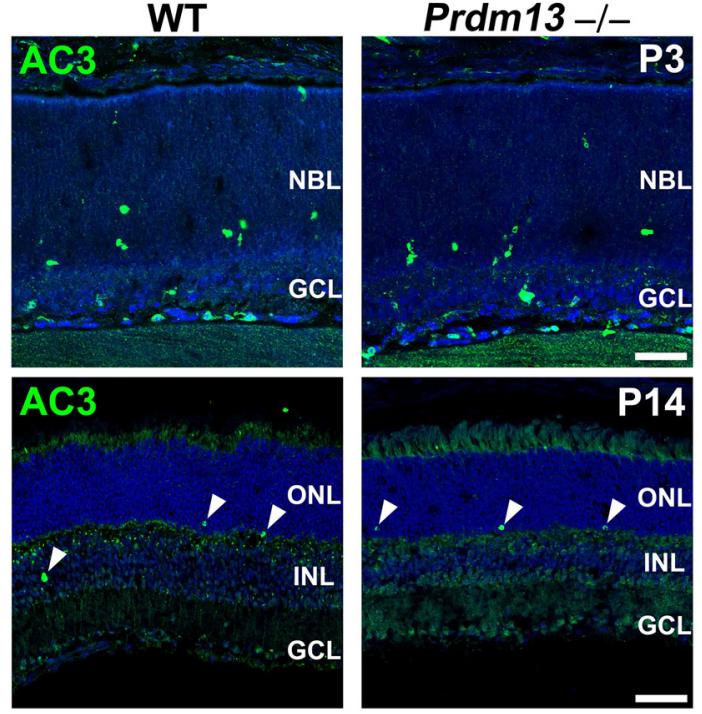

Figure 3. Histological analysis of developing and mature retinas in $\operatorname{Prdm} 13^{-/-}$mice. $\boldsymbol{A}, \boldsymbol{B}$, Toluidine blue staining of the WT and Prdm $13^{-1-}$ retinas at 5 months. Thicknesses of ONL, INL + IPL, INL, and IPL were measured (B).C, The numbers of apoptotic cells were counted in WT and Prdm $13^{-1-}$ retinas at P3 and P14. D, AC3 (active Caspase-3, green) is a marker for apoptotic cells. Arrowheads indicate $\mathrm{AC}^{+}$cells. Nuclei were stained with Hoechst (blue signals). Scale bars, $50 \mu \mathrm{m}$. Error bars indicate the SD from the means of 3 different mice. ${ }^{*} p<0.05$. ${ }^{* *} p<0.01$.

rods, bipolar cells, or amacrine cells at a ratio of 23\%-32\% (Fig. $5 A, B)$. In retinas overexpressing Prdm13, $86.1 \pm 6.6 \%$ of EGFP ${ }^{+}$ cells were $\mathrm{Pax}^{+}{ }^{+}$, whereas Rho and Chx10 were expressed in a very small population $(2.0 \%-5.2 \%$; Fig. $5 A, B)$. This result showed that Prdm13 can potently induce amacrine cell differentiation. The Prdm 13 protein contains a PR-domain similar to the SET domain related to histone methyltransferase activity in the $\mathrm{N}$ terminus and four zinc finger domains in the $\mathrm{C}$ terminus. Then to determine which domain of the $\operatorname{Prdm} 13$ protein is responsible for this activity, we generated constructs expressing a PR domain of Prdm13 (PR domain), four zinc finger domains of Prdm13 (zinc finger domain), and a full length of Prdm13 with mutations leading to inactivation of the four zinc finger domains (zinc fin- ger mutant) (Fig. 5C) (Chang et al., 2013). The PR domaincontaining retinas showed a similar cell composition with that of control retinas (Fig. 5D,E). The zinc finger domain-transfected retinas exhibited a potent induction of amacrine cells at a similar level to that by the full length; however, this effect was not observed in the zinc finger mutant retinas (Fig. $5 D, E$ ). Together, we showed that Prdm13 can potently induce amacrine cell differentiation, and the four zinc finger domains of Prdm13 are responsible for this effect.

\section{$\operatorname{Prdm} 13$ induces more specific amacrine subtypes than Ptfla does}

Ptfla, a bHLH transcription factor, acts directly upstream of Prdm13 (Chang et al., 2013). The targeted disruption of Ptfla in the mouse retina results in a complete absence of horizontal cells and a severe reduction in cell numbers of amacrine cells, indicating that the $\mathrm{Ptfla} \mathrm{a}^{-/-}$retina displays more severe phenotypes than the $\operatorname{Prdm} 13^{-1-}$ retina. In addition, we confirmed that Prdm 13 expression was totally lost in the Ptfla ${ }^{-1-}$ (Kawaguchi et al., 2002) retina at E17.5 (Fig. 6A) (Chang et al., 2013). To examine whether Ptfla and Prdm13 can induce amacrine cell differentiation, we performed in vivo electroporation of pCIG-Prdm 13 or pCIG-Ptf1a into P0 retinas and analyzed induced amacrine subtypes by immunohistochemistry at P14. We first observed that in vivo electroporated $P t f 1 a$ strongly promoted amacrine cell differentiation $\left(93.6 \pm 8.3 \%\right.$ of $\mathrm{EGFP}^{+}$cells; Fig. $\left.6 \mathrm{~B}, \mathrm{C}\right)$. We immunostained control and Prdm13- or Ptf1a-electroporated retinas using an anti-GFP antibody together with an anti-AP- $2 \alpha$ antibody, an anti-AP- $2 \gamma$ antibody, which mainly marks GABAergic and glycinergic amacrine cells, or anti-Islet1/anti-CALBs antibodies, which mark cholinergic amacrine cells at P14. Whereas $48.5 \pm 3.2 \%$ of $\operatorname{Prdm} 13$-electroporated cells were positive for AP- $2 \alpha, 17.0 \pm 2.4 \%$ of Ptf1a-electroporated cells were AP- $2 \alpha^{+}$ (Fig. 6D,G). AP- $2 \gamma^{+}$amacrine cells were induced at a similar level in both Prdm13- or Ptfla-electroporated retinas (pCIGPrdm13: $23.6 \pm 2.0 \%$ and pCIG-Ptf1a: $25.5 \pm 1.9 \%$; Fig. $6 E, G$ ). In contrast to relatively weak AP- $2 \alpha$ induction, Ptfla stimulated the differentiation of Islet $1^{+}$and $\mathrm{CALBs}^{+}$cholinergic amacrine cells much more strongly than Prdm13 did (pCIG-Prdm13: $9.6 \pm 1.9 \%$, pCIG-Ptfla: $35.0 \pm 4.7 \%, p<0.01$; Fig. $6 F, G$ ). These data suggested that $\operatorname{Prdm} 13$ preferentially induced GABAergic and glycinergic amacrine cells, but Ptf1a induced GABAergic, glycinergic, and cholinergic amacrine cells.

It was reported that a very small population of amacrine cells remains in the $\mathrm{Ptfla}{ }^{-1-}$ retina (Fujitani et al., 2006; Nakhai et al., 2007). To confirm that loss of Ptfla affects AP $-2 \alpha^{+}$and cholinergic amacrine cells in the retina, we immunostained WT and Ptf $1 a^{-1-}$ retinas at E17.5 with anti-AP-2 $\alpha$ and anti-Islet1/Brn3b antibodies. We observed a complete loss of AP $-2 \alpha^{+}$amacrine cells and a dramatic reduction of Islet $1^{+} / \mathrm{Brn} 3 \mathrm{~b}^{-}$cells, which mark mainly cholinergic amacrine cells at E17.5, in the Ptfla ${ }^{-/-}$ retina (Fig. $6 \mathrm{H}-\mathrm{J}$ ), suggesting that Ptfla is required for the specification of both AP- $2 \alpha^{+}$GABAergic/glycinergic and Islet ${ }^{+}$ cholinergic amacrine cells. Together, it suggested that Ptfla regulates the subtype specification in a broader range than Prdm13 does.

\section{$\operatorname{Prdm} 13^{-/-}$retinas display a defect of the S2/S3 border in} the IPL

Amacrine cells project into the IPL where their processes densely stratify. Immunostaining of CALBs visualizes three parallel borders, dense neurite bundles of CALBs ${ }^{+}$amacrine cells that contact ganglion cell dendrites and separate the IPL into the 

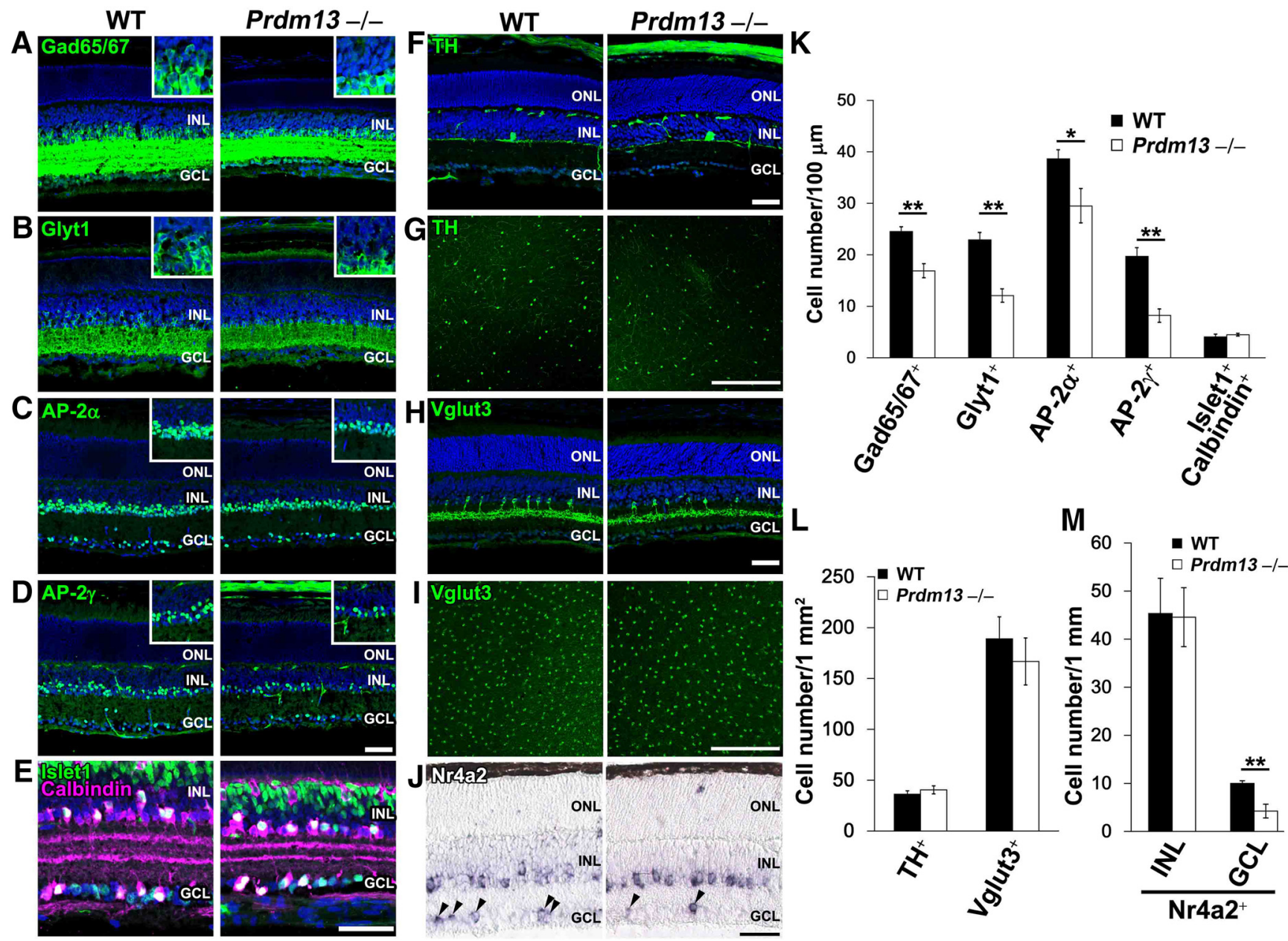

Figure 4. Decrease of GABAergic and glycinergic amacrine cells in the Prdm $13^{-1-}$ retina. A-I, Sections or whole-mounts from WT and Prdm $13^{-/-}$retinas at P14 were immunostained with antibodies against amacrine cell markers (green): Gad65/67 for GABAergic amacrine cells (A), Glyt1 for glycinergic amacrine cells (B), AP-2 $\alpha$ and AP2 $\gamma$ for each different amacrine cell population including GABAergic and glycinergic cells $(\boldsymbol{C}, \boldsymbol{D})$, Islet1 (green) and Calbindin (magenta) for cholinergic amacrine cells (starburst amacrine cells) (E), TH (green) for dopaminergic amacrine cells $(\boldsymbol{F}$,

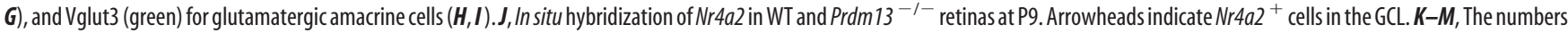
of eight subtypes of amacrine cells in WT and Prdm $13^{-1-}$ retinas at P14 were counted. Nuclei were stained with Hoechst (blue signals). Insets, INL area with high magnification. Error bars indicate SD from the means of 3 or 4 different mice. ${ }^{* *} p<0.01$. ${ }^{*} p<0.05$. Scale bars, $50 \mu \mathrm{m}$.

sublayers S1, S2, S3, S4, and S5 (Wässle, 2004). To examine IPL formation in the $\operatorname{Prdm} 13^{-1-}$ retina, we immunostained WT and $\operatorname{Prdm} 13^{-1-}$ retinas at P14 with antibodies against CALBs (Fig. $7 A, B)$. We observed a deficiency in the border between the S2 and S3 sublayers in the IPL in the Prdm13 $3^{-1-}$ retina (Fig. $7 A, B$, a layer marked with orange color bars). We also observed a significant decrease in the cell numbers of CALBs ${ }^{+}$amacrine cells by $\sim 30 \%$ compared with the WT retina (Fig. $7 C$ ). Furthermore, to confirm that the S2/S3 border bundle in the IPL is deficient in the $\operatorname{Prdm} 13^{-1-}$ retina, we coimmunostained WT and $\operatorname{Prdm} 13^{-1-}$ retinas with an anti-Calretinin antibody to label the three borders and an anti-Calsenilin or an anti-Vglut3 antibody to specifically label the S2 and S3 sublayers. Although calsenilin and Vglut3 signals were seen on the S2 and S3 sublayers in both WT and $\operatorname{Prdm} 13^{-1-}$ retinas, the S2/S3 border bundle labeled with the anti-Calretinin antibody disappeared in the $\operatorname{Prdm} 13^{-1-}$ retina (Fig. $7 D-I$ ). These results showed that a loss of Prdm13 leads to a specific reduction of $\sim 30 \%$ of the CALBs ${ }^{+}$amacrine cells that project to the S2/S3 border in the INL.

$\operatorname{Prdm} 13^{-1-}$ mice exhibit elevated visual sensitivities in OKRs To test visual function in the $\operatorname{Prdm} 13^{-1-}$ mice, we first performed ERG recordings under scotopic and photopic conditions with several light intensities in WT and $\operatorname{Prdm} 13^{-1-}$ mice at 2 months (Fig. 8). Both WT and Prdm $13^{-1-}$ mice displayed typical a- and b-waveforms and the same levels of amplitudes in both scotopic and photopic conditions (Fig. 8A-F). These results were consistent with no observable change in photoreceptor cells and bipolar cells in the $\mathrm{Prdm} 13^{-1-}$ retina (Fig. 2I,J,L,O). In addition, we analyzed oscillatory potential waves (OPs), which are several feedback wavelets and are thought to be derived from amacrine cells (Wachtmeister, 1998). Prdm13 ${ }^{-1-}$ mice showed normal waveforms and amplitudes of OPs in both scotopic and photopic conditions (Fig. 8G-J). We did not detect any differences between WT and Prdm $13^{-1-}$ mice in the ERG analysis.

To investigate the effect of loss of $\operatorname{Prdm} 13$ on visual function, we next measured OKRs in WT and Prdm13 $3^{-1-}$ mice. OKR is a reflexive eye movement observed in responding to moving objects (Distler et al., 1999; Stahl, 2004; Büttner and Kremmyda, 2007) (Fig. 9A,B) that can be divided into initial and late phase based on time range during eye movement (Gellman et al., 1990; Tabata et al., 2010). Initial OKR is observed in a very short period within $500 \mathrm{~ms}$ after visually sensing a moving object, whereas late OKR (also known as optokinetic nystagmus) is a series of eye movements alternating slow tracking and quick resetting to initial eye position within a longer time period (30 $s$ in this study). 
A

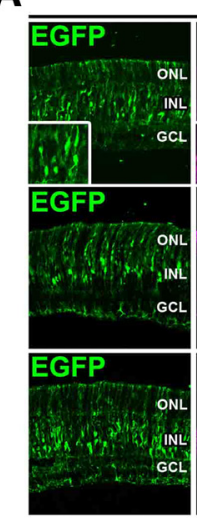

C
PCIG

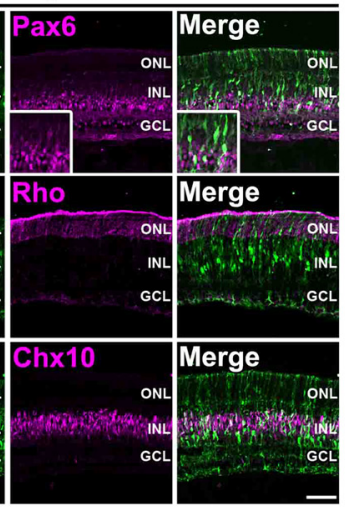

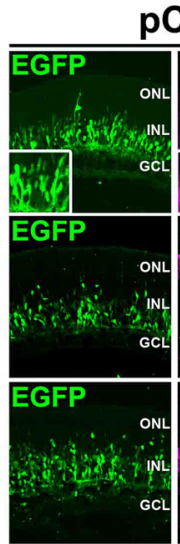

pCIG-Prdm13
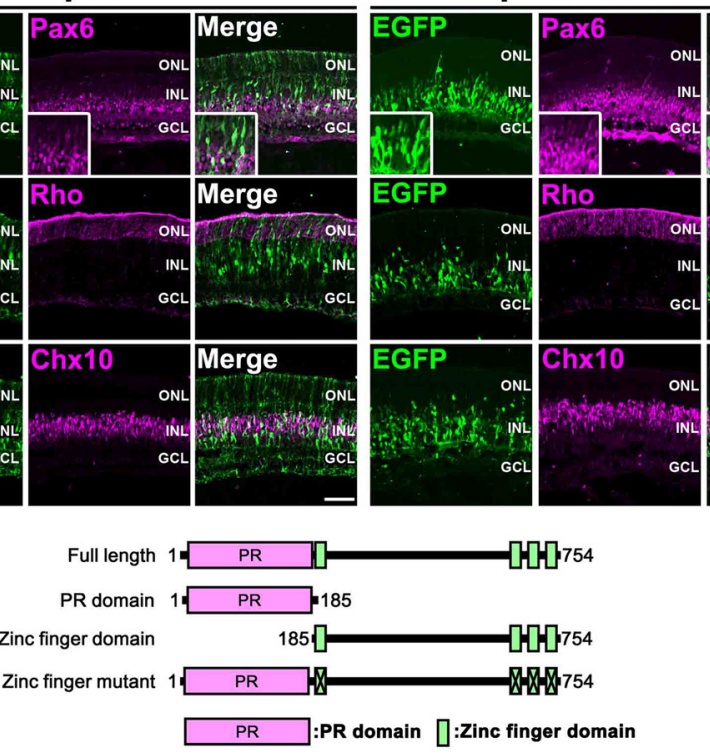

E

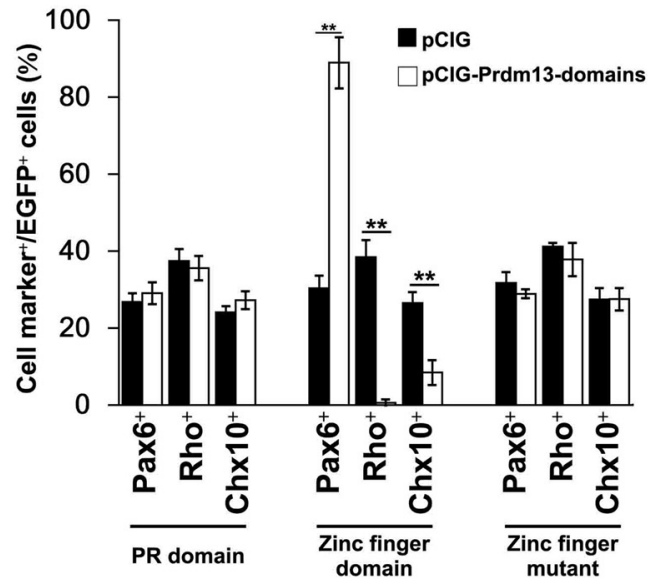

B

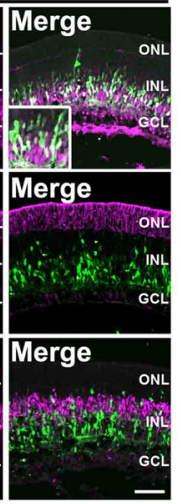

D

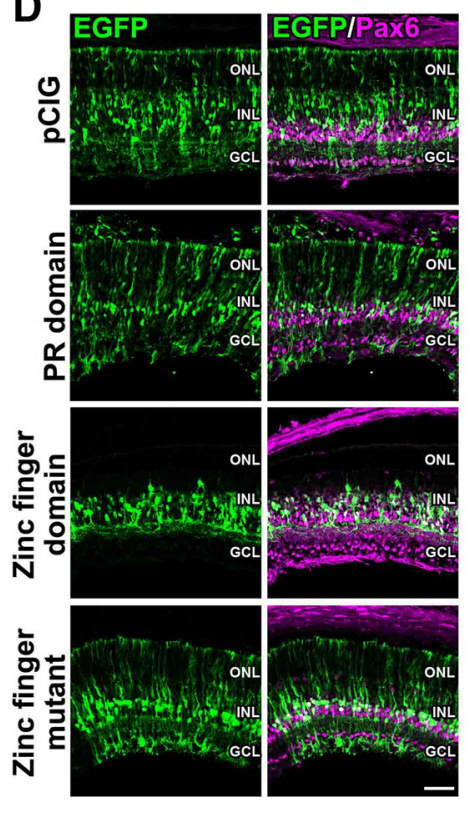

Figure 5. Prdm 13 potently induces differentiation of amacrine cells. $A$, The pCIG (empty vector) or p CIG-Prdm 13 plasmids were electroporated into P0 mouse retinas. The retinas were harvested at P6, sectioned, and immunostained with antibodies against GFP (green) and three retinal cell type-specific markers (magenta): Rhodopsin (Rho, a rod photoreceptor marker), Chx10 (a pan-bipolar cell marker), or Pax6 (a pan-amacrine cell marker). The electroporated cells express EGFP mediated by the IRES sequence. Insets, INL area with high magnification. $\boldsymbol{B}$, The numbers of retinal cell type-specific marker-positive cells of EGFP-positive cells in pCIG or pCIG-Prdm13 electroporated retinas were counted. C, Schematic representation of a full length of Prdm 13 and its mutants used for in vivo electroporation into P0 mouse retinas. D, E, Retinas electroporated with pCIG, pCIG-Prdm13, or pCIG-Prdm13-mutants (pCIG-PR domain, pCIG-zinc finger domain, and pCIG-zinc finger mutant) were immunostained with antibodies against EGFP (green) and cell-type specific markers, including Pax6, Rhodopsin (Rho), or Chx10. Immunostaining images of electroporated retinas with an anti-EGFP antibody (green) and an anti-Pax6 antibody (magenta) were displayed (D). The numbers of retinal cell type-specific marker-positive cells of EGFP-positive cells were counted (E). Error bars indicate SD from the means of $3-5$ different mice. ${ }^{* *} p<0.01$. Scale bars, $50 \mu \mathrm{m}$.

We quantitatively measured OKRs in WT and $\operatorname{Prdm} 13^{-1-}$ mice by plotting mean amplitudes for each visual stimulus in the coordinate system of spatial and temporal frequencies (Fig. $9 C, E, G, I)$. We also visualized quantified OKR responses of WT and $\operatorname{Prdm} 13^{-1-}$ mice as a heat-map (Fig. 9D, F, H,J). In the initial OKRs, $\operatorname{Prdm} 13^{-1-}$ mice showed OKR responses to a broader range of SF and TF than WT mice (Fig. 9C-F; SF: WT 0.06-0.25 cycles/deg, Prdm13 ${ }^{-1-}$ 0.03-0.25 cycles/deg; TF: WT: 0.75-12 $\mathrm{Hz}, \operatorname{Prdm} 13^{-1-} 0.375-12 \mathrm{~Hz}$ ). Consistent with the initial OKRs, in the late OKRs, $\operatorname{Prdm} 13^{-1-}$ mice displayed OKR responses to a broader range of SF and TF compared with WT mice (Fig. 9G-J; SF: WT $0.12-0.25$ cycles/deg, Prdm $13^{-1-} 0.03-0.25$ cycles/deg; TF: WT: $0.75-3 \mathrm{~Hz}, \operatorname{Prdm} 13^{-1-} 0.187-12 \mathrm{~Hz}$ ). Moreover, in both initial and late OKRs, the eye speeds at the optimal response were significantly higher in $\operatorname{Prdm} 13^{-1-}$ mice (Fig. $9 \mathrm{~K}, L$ ). These data suggest that $\operatorname{Prdm} 13^{-1-}$ mice show significantly elevated sensitivities to visual stimuli. We furthermore examined contrast sen- sitivity in WT and Prdm13 $13^{-1-}$ mice. We exposed mice to eight contrast levels (1\%-96\%) of visual stimuli constant in SF $(0.125$ cycles/deg) and TF $(1.5 \mathrm{~Hz})$, to which both WT and $\operatorname{Prdm} 13^{-1-}$ mice showed the same levels of OKR amplitudes. Prdm13 $13^{-1-}$ mice exhibited significantly higher responses to $8 \%, 16 \%$, and 96\% contrast levels than WT mice (Fig. 9M), suggesting that $\operatorname{Prdm} 13^{-1-}$ mice can detect significantly lower contrast objects compared with WT mice (Fig. 9M). Finally, to examine whether abnormalities in the retina in $\operatorname{Prdm} 13^{-1-}$ mice are responsible for the OKR alterations, we analyzed OKRs in Prdm13 CKO mice obtained by crossing Prdm13 flox mouse with Dkk3-Cre transgenic mice, which express Cre predominantly in embryonic retinal progenitor cells (Fig. 2A,B) (Sato et al., 2007). Before OKR analysis, we confirmed that Prdm13 CKO showed the same histological phenotypes as $\operatorname{Prdm} 13^{-1-}$ mice (Fig. 10A-F). In initial OKRs, Prdm13 CKO mice showed higher responses to visual stimuli with a broader range of SF and TF than those observed in 


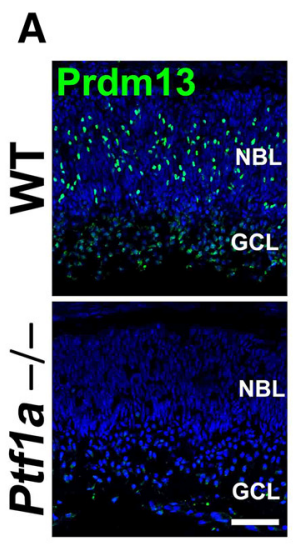

B

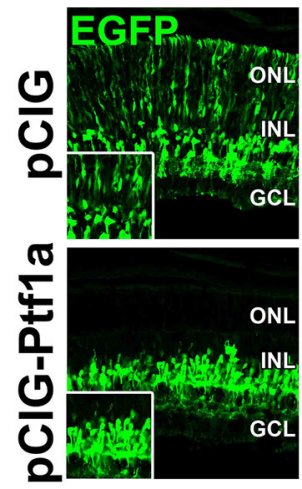

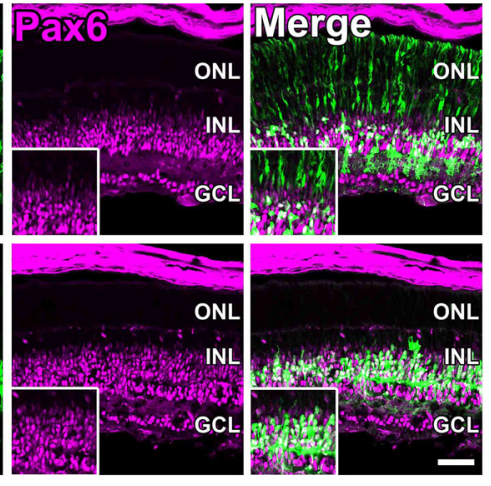

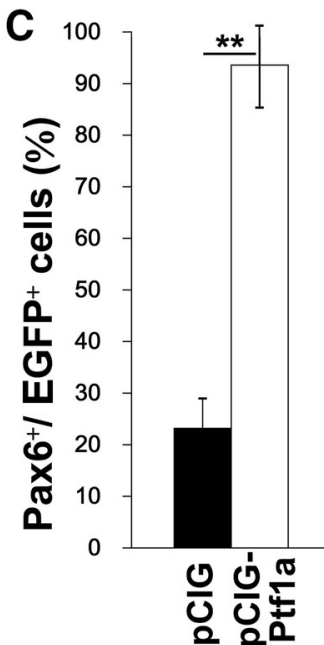

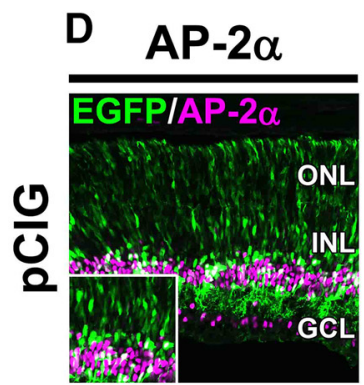

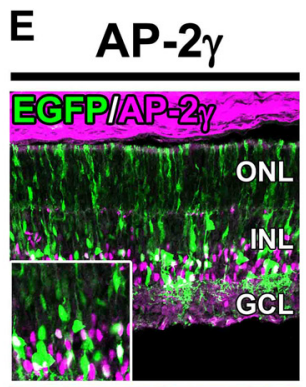

$\mathbf{F}$

Islet1/CALBs
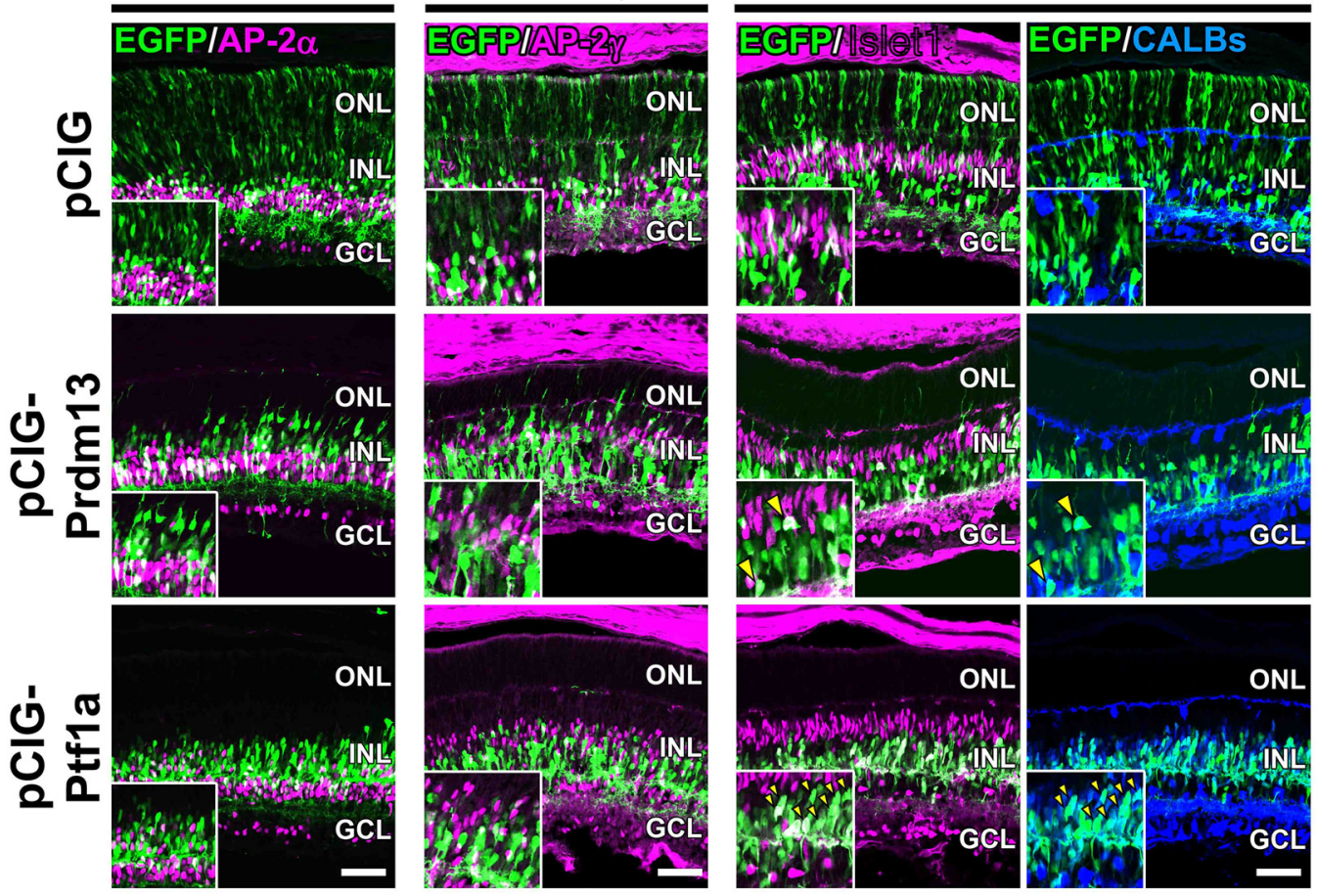

\section{G}
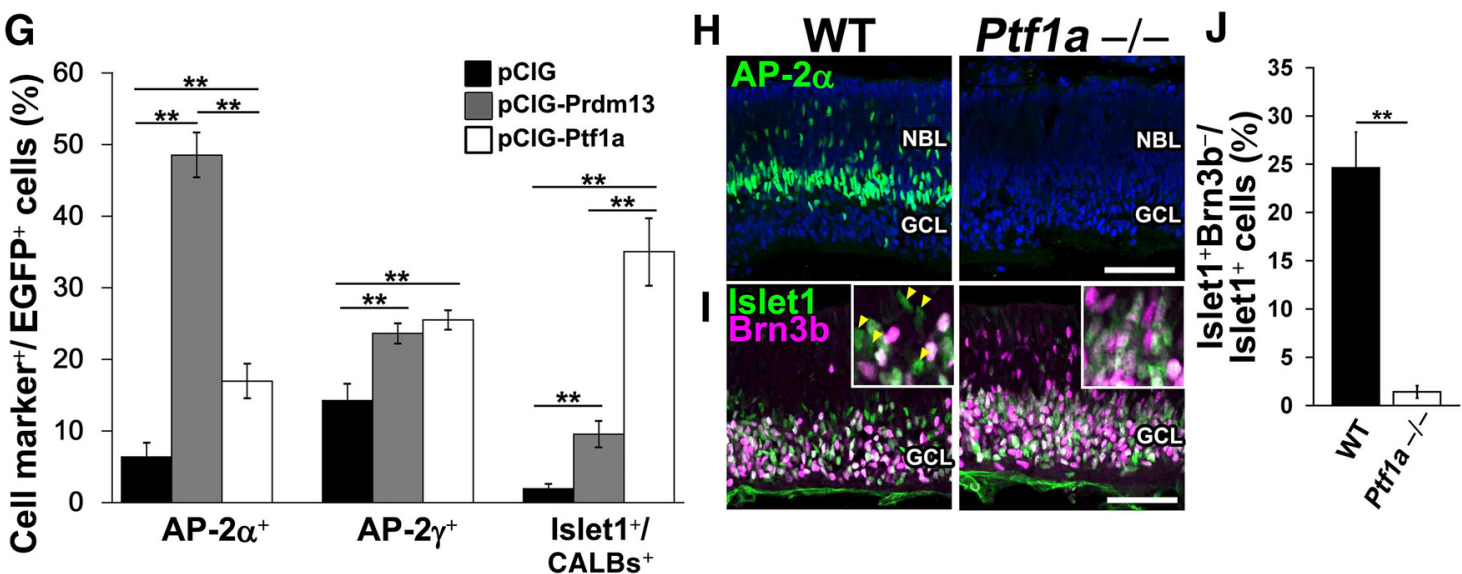

Figure 6. Amacrine cell induction by Prdm 13 and Ptf1a. $A$, WT and Ptf1a ${ }^{-1-}$ retinas at E17.5 were immunostained with antibodies against Prdm13 (green, $A$ ). Nuclei were stained with Hoechst (blue signals). $\boldsymbol{B}$, C, Retinas electroporated with pCIG or pCIG-Ptf1 a constructs at P0 were harvested at P6 and immunostained with antibodies against EGFP (green) and Pax6 (magenta). The numbers of Pax6 ${ }^{+}$cells (magenta) of EGFP ${ }^{+}$cells (green) in the retina electroporated with $\mathrm{PCIG}$ or pCIG-Ptfla were counted (C). Insets, INL area with high magnification (B). $\boldsymbol{D}-\mathbf{G}$, Retinas electroporated with pCIG, pCIG-Prdm13, or pCIG-Ptf1a plasmid were immunostained with antibodies against EGFP (green) and amacrine cell markers: AP-2 $\alpha$ (D, magenta) and AP-2 $\gamma$ (Figure legend continues.) 

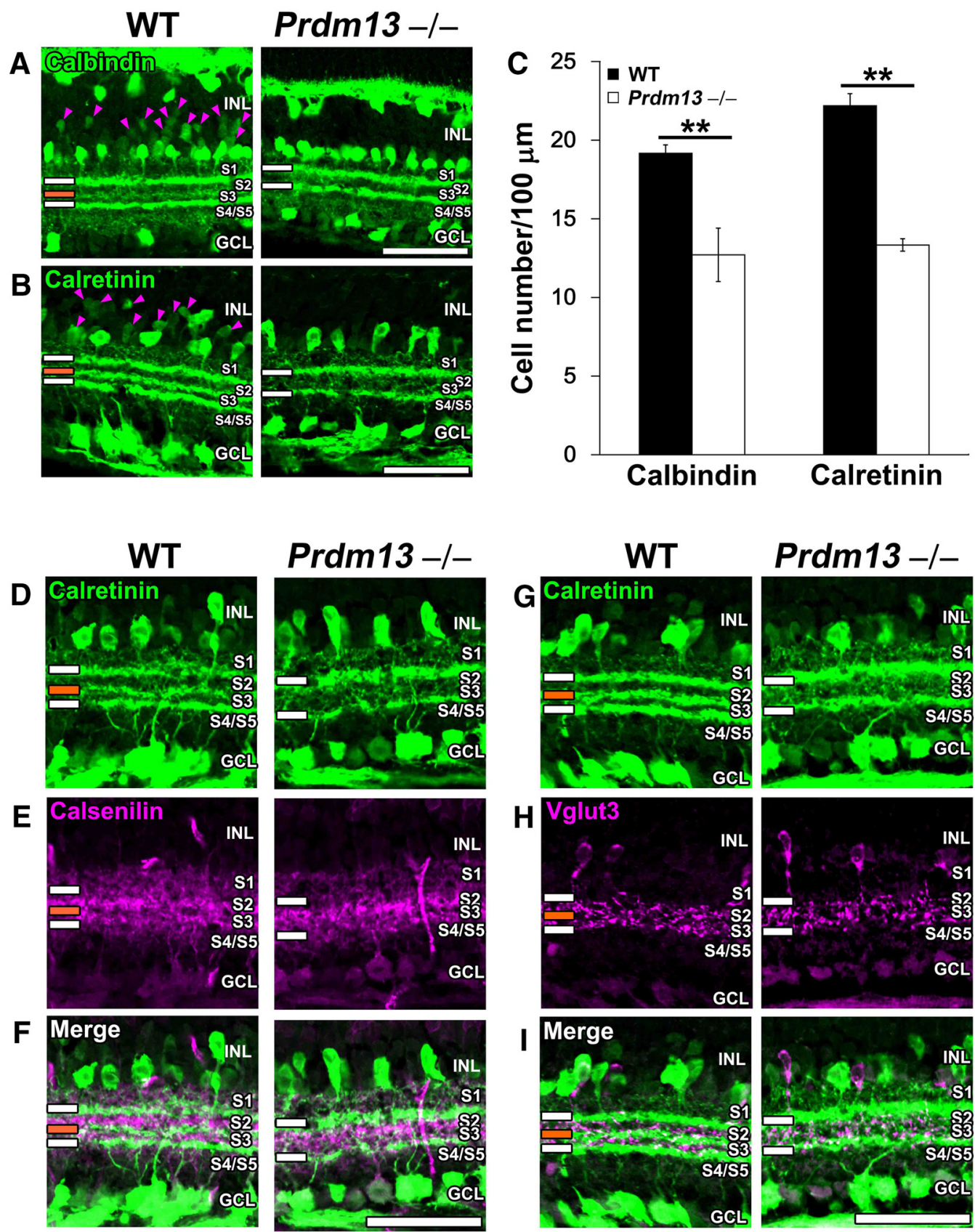

Figure 7. Loss of Prdm13 abolishes the S2/S3 border bundle in the IPL. $\boldsymbol{A}-\boldsymbol{C}$, WT and Prdm $13^{-/-}$retinas at P14 were immunostained with an anti-Calbindin $(\boldsymbol{A})$ or an anti-Calretinin $(\boldsymbol{B})$ antibody. Calbindin- or Calretinin-positive cells localized to the outer edge of the INL disappeared in the Prdm $13^{-1-}$ retina (arrowheads). The numbers of Calbindin ${ }^{+}$or Calretinin ${ }^{+}$amacrine cells in the INL in WT and Prdm $13^{-I-}$ retinas were counted (C).D-I, WT and Prdm $13^{-1-}$ retinas at P14 were immunostained with antibodies against Calretinin (green), which visualizes three sublayers in the IPL and Calsenilin $\left(\boldsymbol{E}, \boldsymbol{F}\right.$, magenta) or Vglut3 $\left(\boldsymbol{H}, \boldsymbol{I}\right.$, magenta), both of which label $S 2$ and $S 3$ layers. Error bars indicate SD from the means of 3 different mice. ${ }^{* *} p<0.01$. Scale bars, $50 \mu \mathrm{m}$.

$\leftarrow$

(figurelegend continued.) (E,magenta) for GABAergic and glycinergic amacrine cells, or Islet1 (magenta) and CALBs (blue) for cholinergic amacrine cells $(\boldsymbol{F})$. Arrowheads indicate EGFP ${ }^{+} /$ Islet $1^{+} / \mathrm{CALBs}^{+}$cells $(\boldsymbol{F})$. The numbers of AP- $2 \alpha^{+}$(left bars), AP- $2 \gamma^{+}$(middle bars), or Islet $1^{+} / \mathrm{CALBs}^{+}$(right bars) cells of EGFP ${ }^{+}$cells in the retinas electroporated with each plasmid were counted $(\boldsymbol{G})$. Insets, INL area with high magnification $(\boldsymbol{D}-\boldsymbol{F})$. Error bars indicate SD from the means of 3 different mice. ${ }^{* *} p<0.01$. $\boldsymbol{H}, \mathbf{I}, \mathrm{WT}$ and $P t f 1 a^{-1-}$ retinas at E17.5 were immunostained with antibodies against AP- $2 \alpha$ (green, $\boldsymbol{H}$ ) and Islet1 (green) plus Brn3b (magenta, II). Insets, Inner NBL area with high magnification (I). Nuclei were stained with Hoechst (blue signals, $\boldsymbol{H}$ ). $\boldsymbol{J}$, The number of Islet $1^{+} / \mathrm{Brn} 3 \mathrm{~b}^{-}$cells of $\mathrm{Islet} 1^{+}$cells was counted. Brn3b is a marker for ganglion cells, and Islet1 marks cholinergic amacrine cells and ganglion cells at E17.5. Islet $1^{+} / \mathrm{Brn} \mathrm{b}^{-}$cells (indicated by arrowheads) are mainly cholinergic amacrine cells. Scale bars, $50 \mu \mathrm{m}$. Error bars indicate SD from the means of 3 different mice. ${ }^{* *} p<0.01$.
WT mice (Fig. 10G-J), showing a similar tendency as the OKRs in $\operatorname{Prdm} 13^{-1-}$ mice. These results suggest that loss of Prdm $13^{+}$ amacrine cells leads to abnormally elevated visual sensitivities, although we cannot completely exclude the possibility that some abnormalities outside the retina affect OKRs.

\section{Discussion}

In the current study, we found that Prdm13 is specifically expressed in developing and mature amacrine cells in the mouse retina. We characterized molecular features of the $\operatorname{Prdm} 13^{+}$ amacrine cells, and observed that the majority of the Prdm $13^{+}$ amacrine cells express CALBs, which label a subset of amacrine cells, including starburst amacrine cells and other amacrine sub- 
A

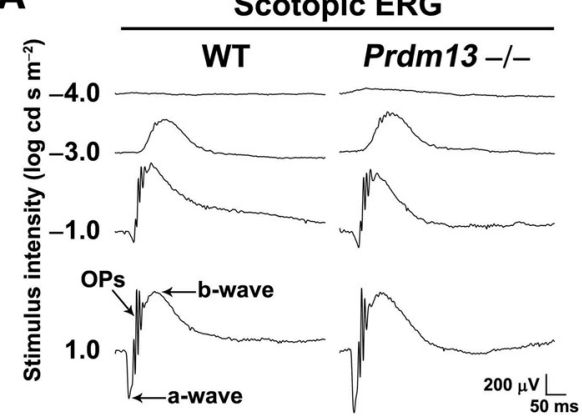

B

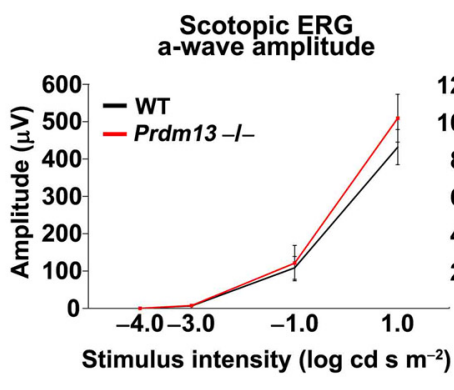

C

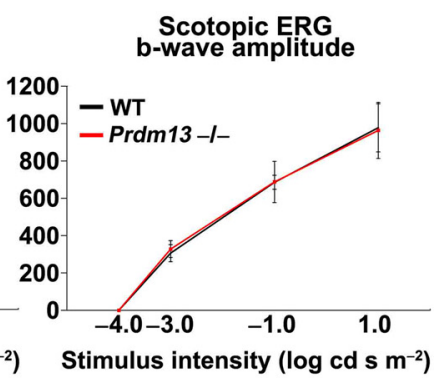

D

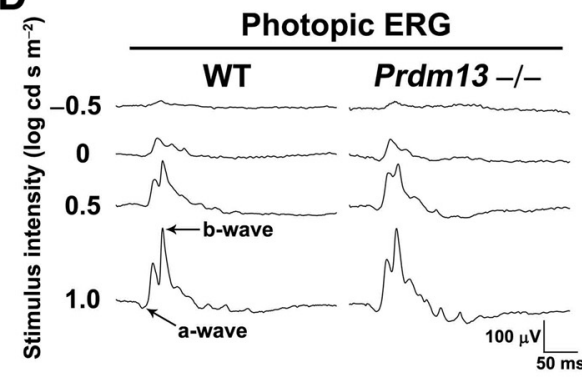

E

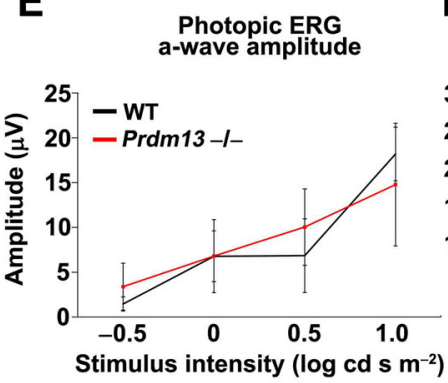

F

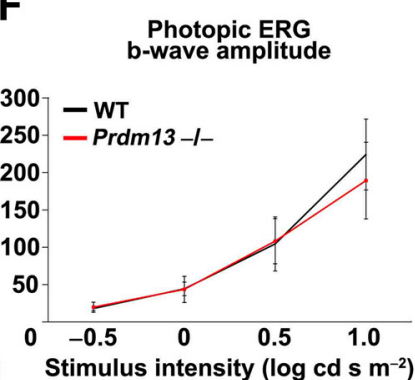

G OPs from scotopic ERG WT

Prdm13-/-
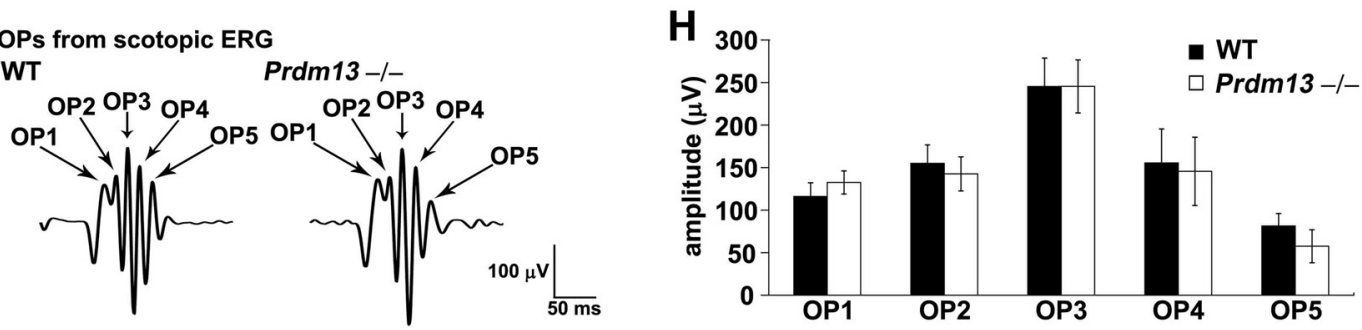

I OPs from photopic ERG
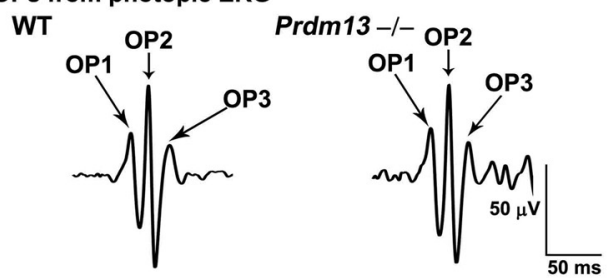

J

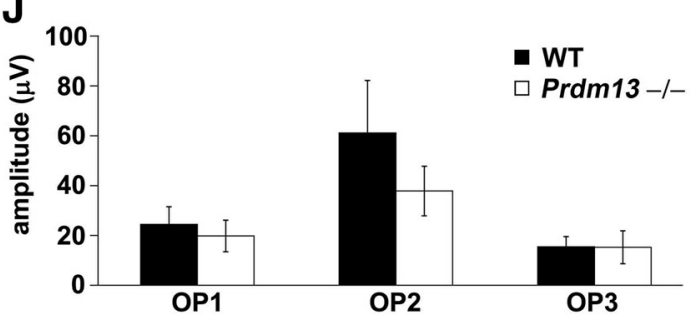

Figure 8. ERG analysis of Prdm $13^{-1-}$ mice. $\boldsymbol{A}-\boldsymbol{F}$, ERGs were recorded from WT $(n=5)$ and Prdm $13^{-1-}(n=6)$ mice at 1 month. Representative scotopic ERG waves in WT and Prdm $13^{-1-}$ mice are presented $(\boldsymbol{A})$. The amplitudes of the scotopic ERG a-wave $(\boldsymbol{B})$ and the b-wave $(\boldsymbol{C})$ are shown as a function of the stimulus intensity. Representative photopic ERG waves in WT and $\operatorname{Prdm} 13^{-1-}$ mice are presented $(\boldsymbol{D})$. The amplitude of the photopic ERG a-wave $(\boldsymbol{E})$ and the b-wave $(\boldsymbol{F})$ in WT and Prdm $13^{-/-}$mice are shown as a function of the stimulus intensity. $\mathbf{G}-\boldsymbol{J}, 0$ Ps are

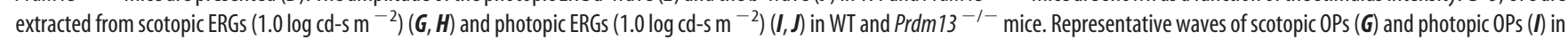
WT and Prdm $13^{-/-}$mice are displayed. Amplitudes of the scotopic OPs (OP1-0P5) (H) and of the photopic OPs (OP1-0P3) (J) were measured in WT and Prdm13 ${ }^{-/-}$mice. Error bars indicate SEM.

types containing GABA, NO, and/or substance P (Haverkamp and Ws̈sle, 2000). However, we did not detect coexpression of Prdm13 with Islet1 (Fig. 1J). Instead, we detected coexpression of Prdm13 with Gad65 or Glyt1, which represents GABAergic or glycinergic amacrine cells respectively (Fig. $1 F, G$ ). Although we observed a significant reduction of GABAergic and glycinergic amacrine cells in the $\operatorname{Prdm} 13^{-/-}$retina, cell numbers of amacrine cells containing other neurotransmitters, such as glutamate, acetylcholine, and dopamine, were not affected in the $\operatorname{Prdm} 13^{-1-}$ retina (Fig. 4). These results indicate that $\operatorname{Prdm} 13^{+}$amacrine cells consist of mainly GABAergic or glycinergic cells, and a small population of other subtypes, except starburst amacrine cells. CALBs label the three strata in the IPL (Fig. 7), with the outermost (S1/S2) and innermost (S3/S4) strata reported to be projections of starburst amacrine cells (Yoshida et al., 2001). Consistent with this observation, loss of $\operatorname{Prdm} 13$ did not affect starburst amacrine cells (Islet ${ }^{+} /$Calbindin ${ }^{+}$cells in the INL) but caused a loss of the CALBs ${ }^{+} \mathrm{S} 2 / \mathrm{S} 3$ border bundle in the IPL (Figs. $4 E, K$, 7 ), showing that the S2/S3 border bundle is projected from Prdm $13^{+}$amacrine cells. Based on these observations, we propose that Prdm13 newly defines a subtype of amacrine cells, which are GABAergic or glycinergic and specifically project to the S2/S3 border in the IPL.

In the spinal cord, Ptf1a directly acts upstream of Prdm13, and both of these factors promote the generation of GABAergic neurons (Chang et al., 2013). However, it had remained unclear whether Prdm13 specifies all of the Ptfla-lineage neurons or whether Prdm13 generates specific subtypes of Ptfla-lineage neurons. In the current study, we obtained two experimental observations supporting the latter hypothesis. First, loss of Ptfla 
A

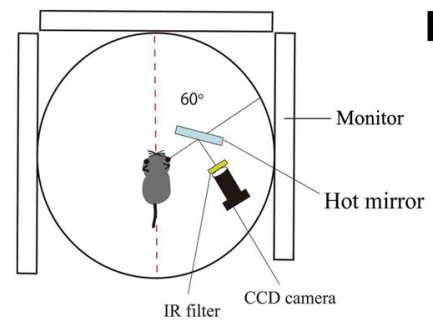

Initial OKR
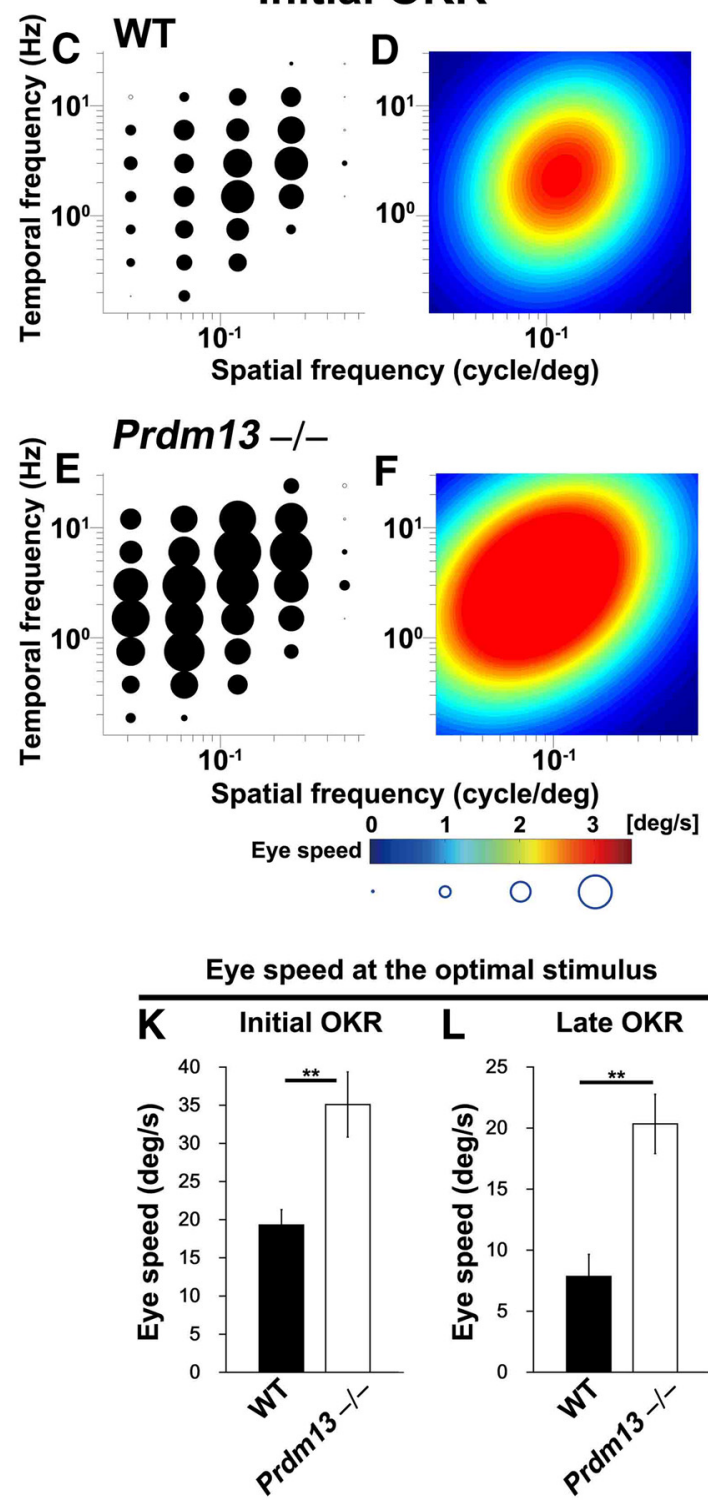

B

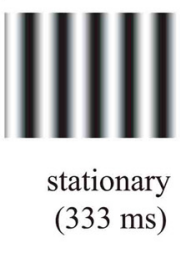

stationary

$0.5 \mathrm{~s}$ (initial phase)

$30 \mathrm{~s}$ (late phase)

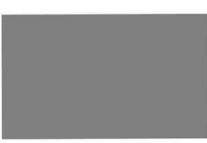

uniform gray

$(2 s)$
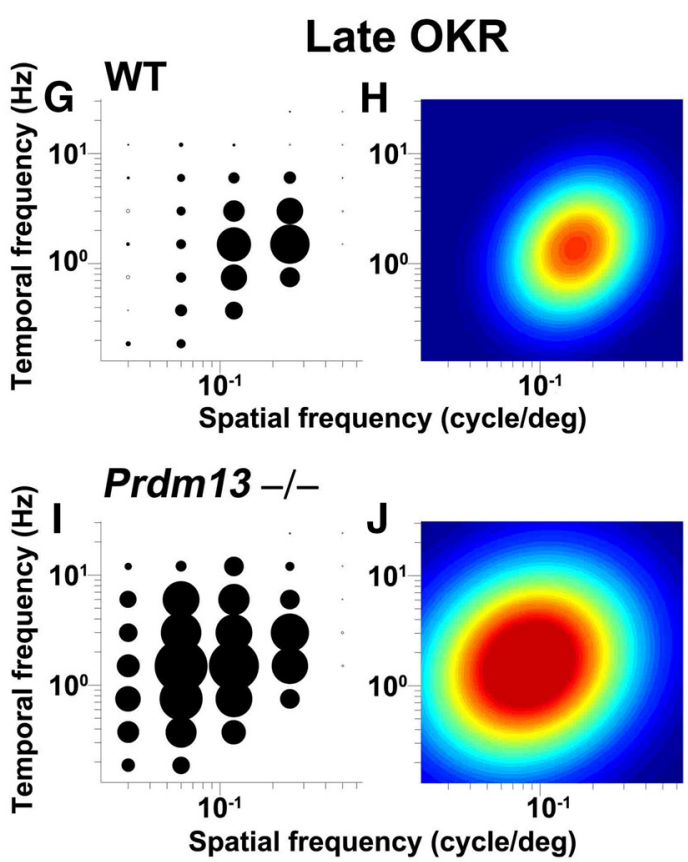

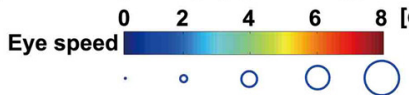

M

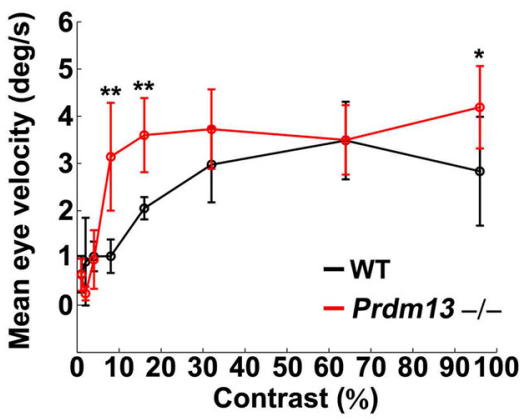

Figure 9. Prdm $13^{-I-}$ mice exhibit elevated visual sensitivities in OKRs. $A, B$, Schematic representation of OKR testing apparatus and procedures. A mouse is placed on a platform, and moving gratings are displayed on the computer screens surrounding the mouse $(A)$. The visual stimulus was presented on three monitors that surround the mouse $(19$-inch $L C D$, refresh rate; $75 \mathrm{~Hz}$, size: $\left.270^{\circ} \times 65.7^{\circ}\right)$. The right eye of the mouse was monitored with a $C(D$ camera to trace the eye tracking. At the beginning of each trial, a stationary visual pattern was presented and then moved counterclockwise or clockwise at a constant speed for $0.5 \mathrm{~s}$ (initial OKR) and $30 \mathrm{~s}$ (late OKR). After a defined period, the pattern was removed to become a uniform gray (B). $\mathbf{C}-\boldsymbol{F}$, Amplitudes of the initial OKRs in WT $(n=5)$ and Prdm $13^{-1-}(n=6)$ mice at 2 months were measured. Amplitudes of the initial OKRs represented by diameter of the circles are plotted in the coordinate system of spatial and temporal frequencies (SF and TF, respectively). Filled symbols represent statistically significant $(t$ test, $p<0.05)$ responses $(C, E)$. Heat-map plots of the best-fit Gaussian functions for the initial OKRs in WT (D) and Prdm 13 ${ }^{-/-}(\boldsymbol{F})$ mice are displayed. G-J, Amplitudes of the late OKRs in WT $(n=8)$ and Prdm $13^{-1-}(n=7)$ mice at 2 months were measured. Filled symbols represent statistically significant responses $(\boldsymbol{G}, \boldsymbol{I})$. Heat-map plots of the best-fit Gaussian functions for the late $0 K R s$ in WT $(\boldsymbol{H})$ and $P r d m 13^{-/-}(\boldsymbol{J})$ mice are shown. $\boldsymbol{K}, \boldsymbol{L}$, Eye speeds at the optimal stimulus in initial OKRs in WT $(n=5)$ and Prdm $13^{-1-}(n=6)$ mice $(\boldsymbol{K})$ and in late OKRs in WT $(n=4)$ and Prdm $13^{-1-}(n=4)$ mice $(\boldsymbol{L})$ are shown. $\boldsymbol{M}$, Contrast sensitivities of WT (black, $\left.n=5\right)$ and Prdm13 ${ }^{-1-}($ red,$n=5)$ mice are plotted. ${ }^{* *} p<0.01 .{ }^{*} p<0.05$. Error bars indicate SD. 

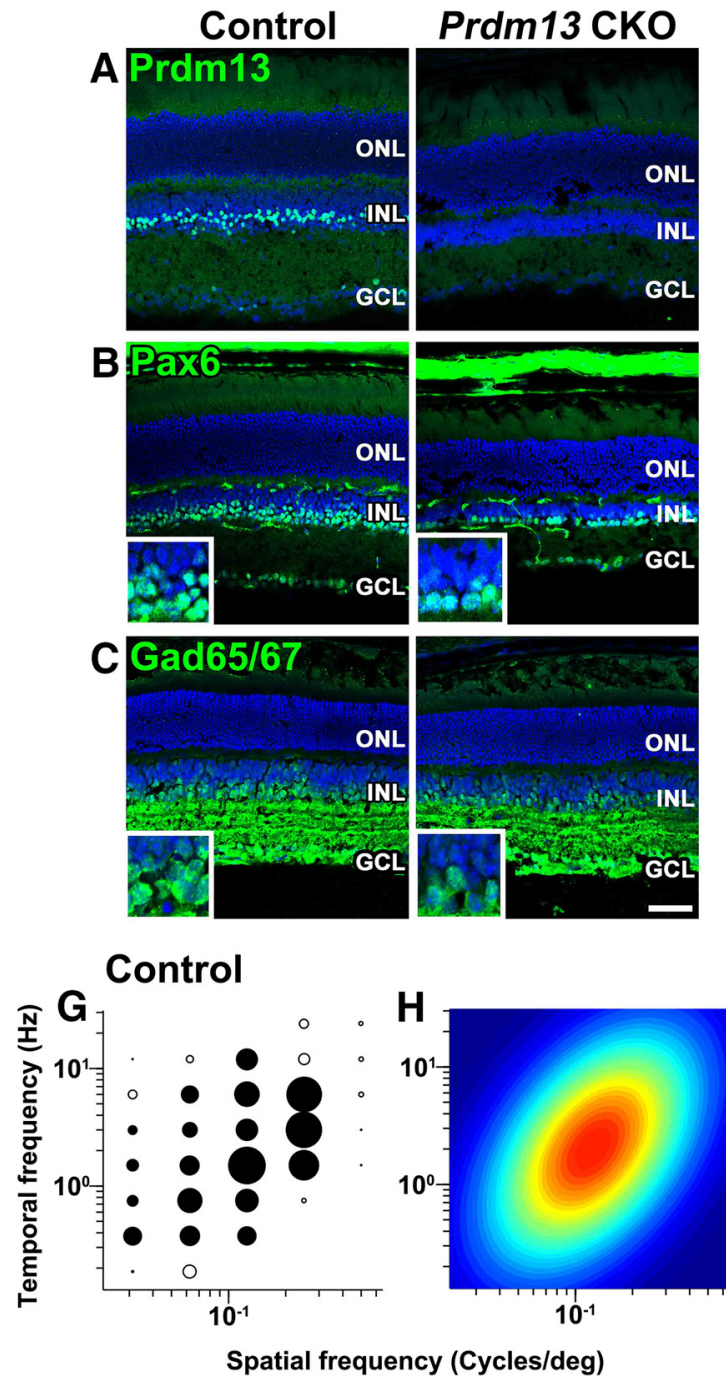
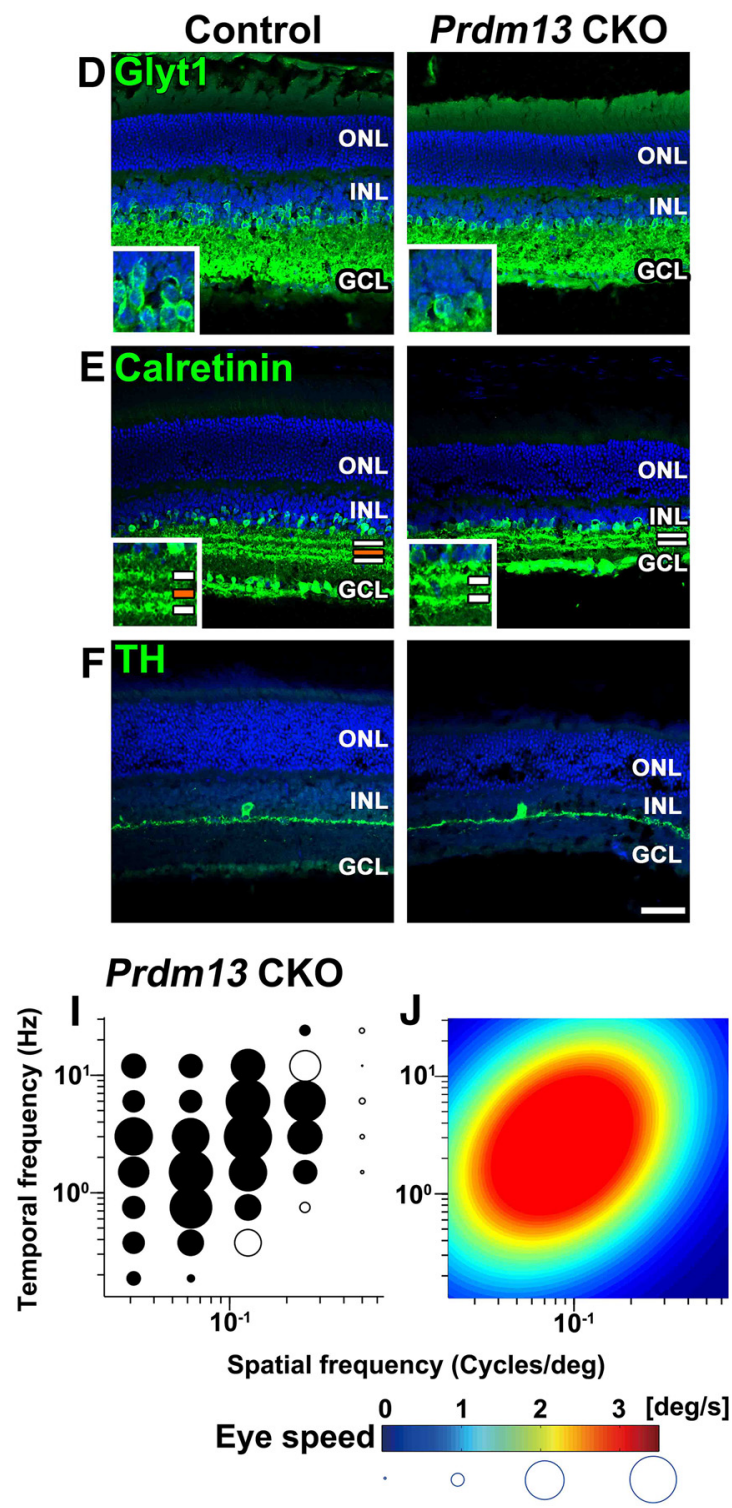

Figure 10. Histological and OKR analyses of Prdm 13 CK0 mice. $\boldsymbol{A}-\boldsymbol{F}$, Control and Prdm 13 CKO retinas at P14 were immunostained with antibodies (green) against Prdm 13 (A), Pax6 (B), Gad65/67 $(\boldsymbol{C})$, Glyt $1(\boldsymbol{D})$, Calretinin $(\boldsymbol{E})$, and TH $(\boldsymbol{F})$. Insets, Inner INL and IPL area with high magnification ( $\boldsymbol{B}-\boldsymbol{D}$ and $\boldsymbol{E}$, respectively). White bars represent the $\mathbf{S 1} / \mathbf{S} 2$ and $\mathrm{S} 3 / \mathrm{S} 4$ border bundles. Orange bars represent the $\$ 2 / S 3$ border bundle in the IPL (E). Nuclei were stained with Hoechst (blue signals). Scale bars, $50 \mu \mathrm{m}$. $\mathbf{G}-\boldsymbol{J}$, Amplitudes of the initial 0 KRs were measured in control and Prdm13 CKO mice at 2 months. Filled circles represent statistically significant $(p<0.05)$ responses $(\boldsymbol{G}, \boldsymbol{I})$. Amplitudes of the initial 0 KRs in control $(\boldsymbol{G})$ and $\operatorname{Prdm} 13$ CKO $(\boldsymbol{I})$ mice are represented by diameter of the circles are plotted in the coordinate system of SF and TF. Heat-map plots of the best-fit Gaussian functions for the initial OKRs in control $(\boldsymbol{H})$ and Prdm 13 CKO (J) mice are presented. G, $\boldsymbol{H}$, ( 0 ntrol mice $(n=3) . \boldsymbol{I}, \boldsymbol{J}, \operatorname{Prdm} 13$ CKO mice $(n=3)$.

in the mouse retina leads to a complete loss of horizontal cells and a vast majority of amacrine cells, specifically almost a complete loss of GABAergic and glycinergic amacrine cells and a severe loss of CALBs $^{+}$amacrine cells (Fujitani et al., 2006; Nakhai et al., 2007) (Fig. $6 A, H, I, J)$. In contrast, $\operatorname{Prdm} 13^{-/-}$mice showed normal cell numbers of horizontal cells but a partial loss of GABAergic/glycinergic amacrine cells. Second, whereas forced expression of Ptfla promoted the specification of both cholinergic amacrine cells (Islet ${ }^{+} /$Calbindin $^{-}$cells) and GABAergic/ glycinergic amacrine cells (AP- $2 \alpha^{+}$and AP- $2 \gamma^{+}$cells), forced expression of Prdm13 preferentially promoted generation of GABAergic/glycinergic amacrine cells. These observations demonstrate that $\operatorname{Prdm} 13$ is related to the specification of more limited amacrine subtypes than Ptfla and suggest that Ptfla upregulates Prdm 13 to subdivide Ptfla-lineage amacrine cells. At the same time, our observations also imply the existence of other downstream factor(s) that diversify Ptfla-lineage retinal neurons (Fig. 11). In the current study, we could not determine whether reduction of amacrine cells in the $\operatorname{Prdm} 13^{-/-}$retina is due to cell fate conversion from amacrine cells to other cell types or simply due to cell death of Prdm $13^{+}$amacrine cells. We did not observe compensatory increases of other retinal cell types in $\operatorname{Prdm} 13^{-1-}$ retinas as far as we examined (Figs. $2 I-O, 4$ ), suggesting that cell fate conversion may not occur in $\operatorname{Prdm} 13^{-1-}$ amacrine cells. However, there remains the possibility that the population of Prdm $13^{+}$amacrine cells is too small to detect compensatory increases in cell numbers of other retinal cell types and to trace Prdm $13^{+}$amacrine cells during development. Future analysis, such as lineage tracing of Prdm $13^{+}$amacrine cells in $\operatorname{Prdm} 13^{-/-}$ retina using, for example, a reporter mouse line expressing Cre recombinase under the $\operatorname{Prdm} 13$ promoter will be necessary to clarify this point. 


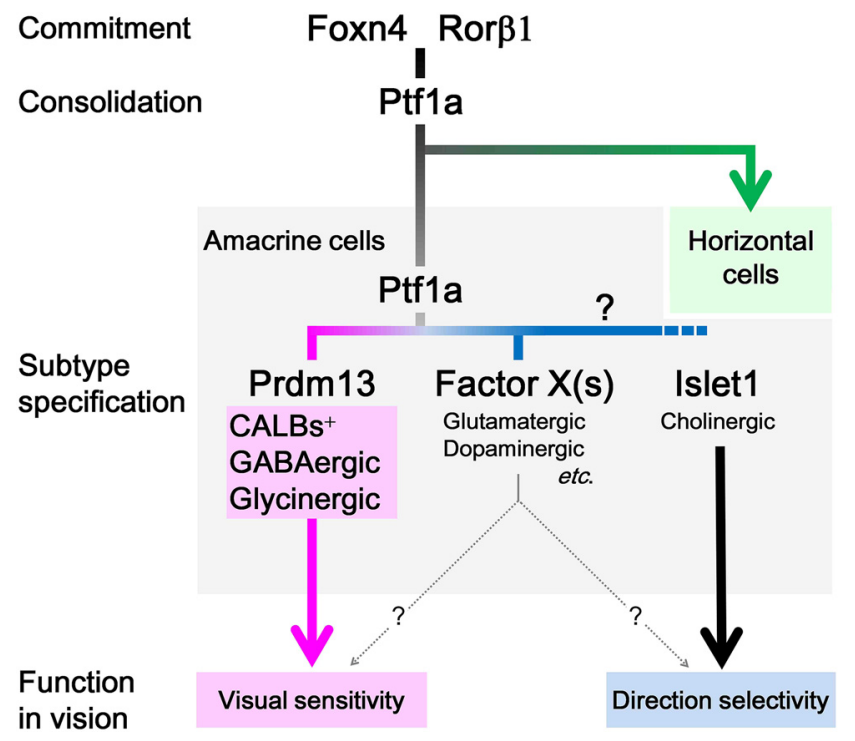

Figure 11. A hypothetical model for Prdm13 function in amacrine cell development. Foxn4 and $\operatorname{Ror} \beta 1$ are expressed in retinal progenitor cells and control the commitment to amacrine and horizontal cell lineages. Ptf1a is upregulated by both Foxn4 and Ror $\beta 1$ and consolidates differentiation of amacrine and horizontal cells. Prdm 13 is downstream of Ptf1a and is responsible for subtype specification of GABAergic, glycinergic, and CALBs ${ }^{+}$amacrine cells. Ptf1a might activate other downstream factor(s) (factor X(s)) regulating a different subset of amacrine cells from those induced by Prdm13. Our current study suggests that the population of amacrine cells, whose development is regulated by Prdm13, is distinct from cholinergic amacrine cells whose development is controlled by Islet1. Prdm $13^{+}$amacrine cells projecting to the S2/S3 border in the IPL modulate visual sensitivity to spatiotemporal frequency and contrast, whereas islet $1^{+}$cholinergic starburst amacrine cells is essential for direction selectivity in vision.

In the chick spinal cord and the Xenopus neural tube during development, Prdm13 was suggested to promote the specification of GABAergic and glycinergic neurons by repressing Tlx3, which is involved in the generation of glutamatergic neurons (Chang et al., 2013; Hanotel et al., 2014). In contrast, we did not observe an increase of glutamatergic amacrine cells labeled with Vglut3 in the Prdm $13^{-1-}$ retina (Fig. $4 H, I, L$ ). Moreover, our previous microarray data from embryonic and postnatal retinas showed that expression levels of the $T l x$ family genes $(T l x 1-3)$ are very low or almost undetectable in the mouse retina (Omori et al., 2011). Therefore, we suppose that the mechanisms of amacrine subtype specification mediated by $\operatorname{Prdm} 13$ are different from those regulating the specification of inhibitory neurons in the spinal cord and neural tube. Our in vivo electroporation experiments in the mouse retina revealed that the zinc finger domain, not the PR domain of Prdm13, is responsible for specification of the amacrine subtypes, consistent with the previous result in the chick spinal cord. A zinc finger domain can mediate DNAbinding and/or protein-protein interaction. Mash1/Ascl1, a proneural bHLH gene, was reported to interact with Prdm13 (Chang et al., 2013). Another proneural bHLH factor, Neurog2 transcriptional activity is suggested to be repressed by Prdm13 (Hanotel et al., 2014). In addition, Prdm8, which exhibits the highest homology to Prdm13 among all of the Prdm family proteins, forms a repressor complex together with bHLHb5 (Ross et al., 2012). These suggest that Prdm13 is likely to form a repressor complex through protein-protein interaction with a bHLH factor. Thus, identification of this bHLH factor will be an important clue in elucidating a detailed molecular mechanism underlying amacrine specification mediated by Prdm13.
In OKRs, we observed higher temporal, spatial, and contrast sensitivities in $\mathrm{Prdm} 13^{-/-}$mice compared with those in WT mice (Figs. 9, 10G-J). The ablation of starburst amacrine cells almost completely abolished OKRs due to inability to detect the direction of moving objects (Yoshida et al., 2001). However, our histological analyses demonstrated that starburst amacrine cells were unaffected in the $\operatorname{Prdm} 13^{-1-}$ retina (Fig. 4 E, K), suggesting that starburst amacrine cells do not contribute to the OKR phenotypes observed in $\mathrm{Prdm} 13^{-/-}$mice (Fig. 9). A previous electrophysiological study suggested that ganglion cells are modulated by NPY-releasing amacrine cells to respond to visual stimuli with low spatial frequency. When this amacrine subtype was ablated, ganglion cell responses to low spatial frequency significantly diminished (Sinclair et al., 2004). Interestingly, Prdm13 $13^{-1-}$ mice showed augmented OKRs to a range of spatial frequencies (Fig. 9). Together, Prdm $13^{+}$amacrine cells projecting to the CALBs ${ }^{+}$ $\mathrm{S} 2 / \mathrm{S} 3$ border bundle in the IPL play important roles in visual processing in the retina (Fig. 11).

To our knowledge, the Prdm13 $13^{-1-}$ mouse is the first mutant mouse in which temporal, spatial, and contrast sensitivities in OKRs are shifted significantly higher than those in WT mouse. What amacrine cell population and neural circuits in the retina are associated with the visual phenotypes in $\operatorname{Prdm} 13^{-/-}$mice? It was reported that Type 2 amacrine cells project to the S2/S3 border bundle in the IPL, contain GABA as a neurotransmitter, and express CALBs (Knop et al., 2011). Because the CALBs ${ }^{+}$S2/S3 border bundle totally disappears in the $\operatorname{Prdm} 13^{-1-}$ retina, we speculate that Type 2 amacrine cells are mainly Prdm13-positive. Type 2 amacrine cells exhibit ON-OFF light responses by transient depolarization to the onset and the offset of a light stimulus and form synapses with Vglut ${ }^{+}$amacrine cells (GACs) containing glutamate and glycine (Knop et al., 2011). Recently, GACs were found to project to both ON type and ON-OFF type direction selective ganglion cells (DSGCs) that are responsible for direction selectivity and play an essential role in OKRs. GACs mediate feedforward and crossover excitations of both types of DSGCs by releasing glutamate (Lee et al., 2014). Immunohistochemical analysis showed that GACs receive projections from Type 2 amacrine cells (Knop et al., 2011). If Type 2 amacrine cells are $\operatorname{Prdm} 13^{+}, \operatorname{Prdm} 13^{+}$amacrine cells may negatively affect DSGC activities through GACs, suggesting a possibility that Prdm13 loss may lead to elevated sensitivities in OKRs through modulation of DSGCs. Future studies to clarify functional interactions among Prdm $13^{+}$amacrine cells, GACs and DSGCs, as well as a possible relationship between $\operatorname{Prdm} 13^{+}$amacrine cells and Type 2 amacrine cells will be needed to exactly understand the physiological roles and functional mechanisms of Prdm $13^{+}$ amacrine cells in the retinal circuit.

Although amacrine interneurons, which are mainly inhibitory neurons, are thought to be crucial for visual information processing in the retina, their complexity makes our understanding of the exact function and mechanism of each amacrine subtype extremely difficult. The current study may shed new light on a functional role of the specific amacrine subtype specifically projecting to the S2/S3 border bundle. We found that visual sensitivities measured by OKR increased without $\operatorname{Prdm13}$ in mice; however, we suspect that there is a deficit in some specific visual function that we cannot assess by OKR or ERG as a trade-off for elevated temporal, spatial, and contrast sensitivities. Future electrophysiological analyses on $\operatorname{Prdm} 13^{+}$amacrine cells at the single-cell level as well as a circuit level will be required to clarify the mechanisms underlying the observed OKR phenotypes in the $\operatorname{Prdm} 13^{-1-}$ mice. 


\section{References}

Balasubramanian R, Gan L (2014) Development of retinal amacrine cells and their dendritic stratification. Curr Ophthalmol Rep 2:100-106. CrossRef Medline

Bassett EA, Korol A, Deschamps PA, Buettner R, Wallace VA, Williams T, West-Mays JA (2012) Overlapping expression patterns and redundant roles for AP-2 transcription factors in the developing mammalian retina. Dev Dyn 241:814-829. CrossRef Medline

Büttner U, Kremmyda O (2007) Smooth pursuit eye movements and optokinetic nystagmus. Dev Ophthalmol 40:76-89. CrossRef Medline

Cepko CL, Austin CP, Yang X, Alexiades M, Ezzeddine D (1996) Cell fate determination in the vertebrate retina. Proc Natl Acad Sci U S A 93:589595. CrossRef Medline

Chang JC, Meredith DM, Mayer PR, Borromeo MD, Lai HC, Ou YH, Johnson JE (2013) Prdm13 mediates the balance of inhibitory and excitatory neurons in somatosensory circuits. Dev Cell 25:182-195. CrossRef Medline

Cossart R (2011) The maturation of cortical interneuron diversity: how multiple developmental journeys shape the emergence of proper network function. Curr Opin Neurobiol 21:160-168. CrossRef Medline

Ding Q, Chen H, Xie X, Libby RT, Tian N, Gan L (2009) BARHL2 differentially regulates the development of retinal amacrine and ganglion neurons. J Neurosci 29:3992-4003. CrossRef Medline

Distler C, Vital-Durand F, Korte R, Korbmacher H, Hoffmann KP (1999) Development of the optokinetic system in macaque monkeys. Vision Res 39:3909-3919. CrossRef Medline

Elshatory Y, Deng M, Xie X, Gan L (2007a) Expression of the LIMhomeodomain protein Isl1 in the developing and mature mouse retina. J Comp Neurol 503:182-197. CrossRef Medline

Elshatory Y, Everhart D, Deng M, Xie X, Barlow RB, Gan L (2007b) Islet-1 controls the differentiation of retinal bipolar and cholinergic amacrine cells. J Neurosci 27:12707-12720. CrossRef Medline

Feng L, Xie X, Joshi PS, Yang Z, Shibasaki K, Chow RL, Gan L (2006) Requirement for Bhlhb5 in the specification of amacrine and cone bipolar subtypes in mouse retina. Development 133:4815-4825. CrossRef Medline

Fujitani Y, Fujitani S, Luo H, Qiu F, Burlison J, Long Q, Kawaguchi Y, Edlund H, MacDonald RJ, Furukawa T, Fujikado T, Magnuson MA, Xiang M, Wright CV (2006) Ptfla determines horizontal and amacrine cell fates during mouse retinal development. Development 133:4439-4450. CrossRef Medline

Gábriel R, Witkovsky P (1998) Cholinergic, but not the rod pathway-related glycinergic (All), amacrine cells contain calretinin in the rat retina. Neurosci Lett 247:179-182. CrossRef Medline

Gellman RS, Carl JR, Miles FA (1990) Short latency ocular-following responses in man. Vis Neurosci 5:107-122. CrossRef Medline

Gollisch T, Meister M (2010) Eye smarter than scientists believed: neural computations in circuits of the retina. Neuron 65:150-164. CrossRef Medline

Grünert U, Wässle H (1993) Immunocytochemical localization of glycine receptors in the mammalian retina. J Comp Neurol 335:523-537. CrossRef Medline

Hanotel J, Bessodes N, Thélie A, Hedderich M, Parain K, Van Driessche B, Brandão Kde O, Kricha S, Jorgensen MC, Grapin-Botton A, Serup P, Van Lint C, Perron M, Pieler T, Henningfeld KA, Bellefroid EJ (2014) The $\operatorname{Prdm} 13$ histone methyltransferase encoding gene is a Ptfla-Rbpj downstream target that suppresses glutamatergic and promotes GABAergic neuronal fate in the dorsal neural tube. Dev Biol 386:340-357. CrossRef Medline

Haverkamp S, Wässle H (2000) Immunocytochemical analysis of the mouse retina. J Comp Neurol 424:1-23. CrossRef Medline

Heynen H, Wachtmeister L, van Norren D (1985) Origin of the oscillatory potentials in the primate retina. Vision Res 25:1365-1373. CrossRef Medline

Iuvone PM (1986) Neurotransmitters and neuromodulators in the retina: regulation, interactions, and cellular effects. In: The retina, a model for cell biology studies, Part II (Ruben Adler DF, ed), pp 1-72. San Diego: Academic.

Jiang H, Xiang M (2009) Subtype specification of GABAergic amacrine cells by the orphan nuclear receptor Nr4a2/Nurr1. J Neurosci 29:1044910459. CrossRef Medline

Kawaguchi Y, Cooper B, Gannon M, Ray M, MacDonald RJ, Wright CV
(2002) The role of the transcriptional regulator Ptfla in converting intestinal to pancreatic progenitors. Nat Genet 32:128-134. CrossRef Medline

Kay JN, Voinescu PE, Chu MW, Sanes JR (2011) Neurod6 expression defines new retinal amacrine cell subtypes and regulates their fate. Nat Neurosci 14:965-972. CrossRef Medline

Klausberger T, Somogyi P (2008) Neuronal diversity and temporal dynamics: the unity of hippocampal circuit operations. Science 321:53-57. CrossRef Medline

Knop GC, Feigenspan A, Weiler R, Dedek K (2011) Inputs underlying the ON-OFF light responses of type 2 wide-field amacrine cells in TH::GFP mice. J Neurosci 31:4780-4791. CrossRef Medline

Koike C, Nishida A, Ueno S, Saito H, Sanuki R, Sato S, Furukawa A, Aizawa S, Matsuo I, Suzuki N, Kondo M, Furukawa T (2007) Functional roles of Otx2 transcription factor in postnatal mouse retinal development. Mol Cell Biol 27:8318-8329. CrossRef Medline

Kolb H (1995) Neurotransmitters in the retina. In: Webvision: the organization of the retina and visual system (Kolb H, Fernandez E, Nelson R, eds). Salt Lake City. http://webvision.med.utah.edu/book/part-ivneurotransmitters-in-the-retina/

Lee S, Chen L, Chen M, Ye M, Seal RP, Zhou ZJ (2014) An unconventional glutamatergic circuit in the retina formed by vGluT3 amacrine cells. Neuron 84:708-715. CrossRef Medline

Li S, Mo Z, Yang X, Price SM, Shen MM, Xiang M (2004) Foxn4 controls the genesis of amacrine and horizontal cells by retinal progenitors. Neuron 43:795-807. CrossRef Medline

Liu H, Kim SY, Fu Y, Wu X, Ng L, Swaroop A, Forrest D (2013) An isoform of retinoid-related orphan receptor beta directs differentiation of retinal amacrine and horizontal interneurons. Nat Commun 4:1813. CrossRef Medline

MacNeil MA, Masland RH (1998) Extreme diversity among amacrine cells: implications for function. Neuron 20:971-982. CrossRef Medline

MacNeil MA, Heussy JK, Dacheux RF, Raviola E, Masland RH (1999) The shapes and numbers of amacrine cells: matching of photofilled with Golgi-stained cells in the rabbit retina and comparison with other mammalian species. J Comp Neurol 413:305-326. CrossRef Medline

Masland RH (2012) The neuronal organization of the retina. Neuron 76: 266-280. CrossRef Medline

Matsuda T, Cepko CL (2004) Electroporation and RNA interference in the rodent retina in vivo and in vitro. Proc Natl Acad Sci U S A 101:16-22. CrossRef Medline

Mattapallil MJ, Wawrousek EF, Chan CC, Zhao H, Roychoudhury J, Ferguson TA, Caspi RR (2012) The Rd8 mutation of the Crb1 gene is present in vendor lines of C57BL/6N mice and embryonic stem cells, and confounds ocular induced mutant phenotypes. Invest Ophthalmol Vis Sci 53:2921-2927. CrossRef Medline

Menger N, Pow DV, Wässle H (1998) Glycinergic amacrine cells of the rat retina. J Comp Neurol 401:34-46. CrossRef Medline

Mo Z, Li S, Yang X, Xiang M (2004) Role of the Barhl2 homeobox gene in the specification of glycinergic amacrine cells. Development 131:16071618. CrossRef Medline

Mojumder DK, Wensel TG, Frishman LJ (2008) Subcellular compartmentalization of two calcium binding proteins, calretinin and calbindin-28 $\mathrm{kDa}$, in ganglion and amacrine cells of the rat retina. Mol Vis 14:16001613. Medline

Muranishi Y, Terada K, Inoue T, Katoh K, Tsujii T, Sanuki R, Kurokawa D, Aizawa S, Tamaki Y, Furukawa T (2011) An essential role for RAX homeoprotein and NOTCH-HES signaling in Otx2 expression in embryonic retinal photoreceptor cell fate determination. J Neurosci 31:1679216807. CrossRef Medline

Nakhai H, Sel S, Favor J, Mendoza-Torres L, Paulsen F, Duncker GI, Schmid RM (2007) Ptfla is essential for the differentiation of GABAergic and glycinergic amacrine cells and horizontal cells in the mouse retina. Development 134:1151-1160. CrossRef Medline

Nishida A, Furukawa A, Koike C, Tano Y, Aizawa S, Matsuo I, Furukawa T (2003) Otx2 homeobox gene controls retinal photoreceptor cell fate and pineal gland development. Nat Neurosci 6:1255-1263. CrossRef Medline Omori Y, Katoh K, Sato S, Muranishi Y, Chaya T, Onishi A, Minami T, Fujikado T, Furukawa T (2011) Analysis of transcriptional regulatory pathways of photoreceptor genes by expression profiling of the Otx2deficient retina. PLoS One 6:e19685. CrossRef Medline

Pettitt SJ, Liang Q, Rairdan XY, Moran JL, Prosser HM, Beier DR, Lloyd KC, 
Bradley A, Skarnes WC (2009) Agouti C57BL/6N embryonic stem cells for mouse genetic resources. Nat Methods 6:493-495. CrossRef Medline

Ross SE, McCord AE, Jung C, Atan D, Mok SI, Hemberg M, Kim TK, Salogiannis J, Hu L, Cohen S, Lin Y, Harrar D, McInnes RR, Greenberg ME (2012) Bhlhb5 and Prdm8 form a repressor complex involved in neuronal circuit assembly. Neuron 73:292-303. CrossRef Medline

Sakai K, Miyazaki Ji (1997) A transgenic mouse line that retains Cre recombinase activity in mature oocytes irrespective of the cre transgene transmission. Biochem Biophys Res Commun 237:318-324. CrossRef Medline

Sanuki R, Onishi A, Koike C, Muramatsu R, Watanabe S, Muranishi Y, Irie S, Uneo S, Koyasu T, Matsui R, Chérasse Y, Urade Y, Watanabe D, Kondo M, Yamashita T, Furukawa T (2011) miR-124a is required for hippocampal axogenesis and retinal cone survival through Lhx2 suppression. Nat Neurosci 14:1125-1134. CrossRef Medline

Sato S, Inoue T, Terada K, Matsuo I, Aizawa S, Tano Y, Fujikado T, Furukawa T (2007) Dkk3-Cre BAC transgenic mouse line: a tool for highly efficient gene deletion in retinal progenitor cells. Genesis 45:502-507. CrossRef Medline

Sinclair JR, Jacobs AL, Nirenberg S (2004) Selective ablation of a class of amacrine cells alters spatial processing in the retina. J Neurosci 24:14591467. CrossRef Medline

Stahl JS (2004) Using eye movements to assess brain function in mice. Vision Res 44:3401-3410. CrossRef Medline
Sugita Y, Miura K, Araki F, Furukawa T, Kawano K (2013) Contributions of retinal direction-selective ganglion cells to optokinetic responses in mice. Eur J Neurosci 38:2823-2831. CrossRef Medline

Tabata H, Shimizu N, Wada Y, Miura K, Kawano K (2010) Initiation of the optokinetic response (OKR) in mice. J Vis 10:13.1-13.17. CrossRef Medline

Völgyi B, Pollak E, Buzás P, Gábriel R (1997) Calretinin in neurochemically well-defined cell populations of rabbit retina. Brain Res 763:79-86. CrossRef Medline

Wachtmeister L (1998) Oscillatory potentials in the retina: what do they reveal. Prog Retin Eye Res 17:485-521. CrossRef Medline

Wässle H (2004) Parallel processing in the mammalian retina. Nat Rev Neurosci 5:747-757. CrossRef Medline

Wässle H, Grünert U, Chun MH, Boycott BB (1995) The rod pathway of the macaque monkey retina: identification of AII-amacrine cells with antibodies against calretinin. J Comp Neurol 361:537-551. CrossRef Medline

Yoshida K, Watanabe D, Ishikane H, Tachibana M, Pastan I, Nakanishi S (2001) A key role of starburst amacrine cells in originating retinal directional selectivity and optokinetic eye movement. Neuron 30:771-780. CrossRef Medline

Zafra F, Aragón C, Olivares L, Danbolt NC, Giménez C, Storm-Mathisen J (1995) Glycine transporters are differentially expressed among CNS cells. J Neurosci 15:3952-3969. Medline 